ANNIE O'CONNOR

CENSORING CYBER-BULLIES: IS THE HARMFUL DIGITAL COMMUNICATIONS BILL A JUSTIFIED LIMITATION ON THE RIGHT TO FREEDOM OF EXPRESSION?

LAWS 520: CENSORSHIP AND THE FREEDOM OF EXPRESSION

Submitted for the LLB (Honours) Degree

FACULTY OF LAW

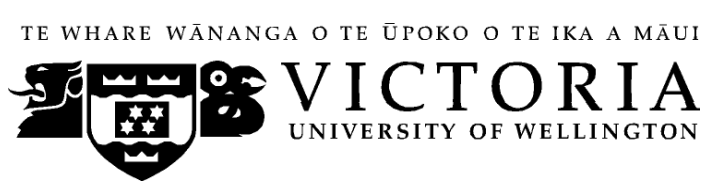

2014 


\section{Table of Contents}

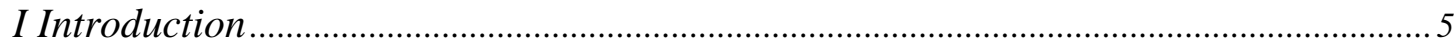

II Harmful Digital Communications: Scope and Effect................................................... 7

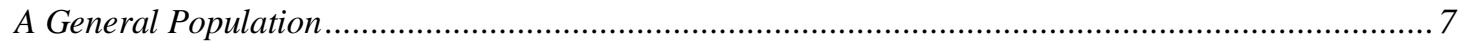

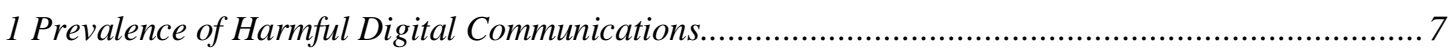

2 Effects of Harmful Digital Communications ............................................................................ 8

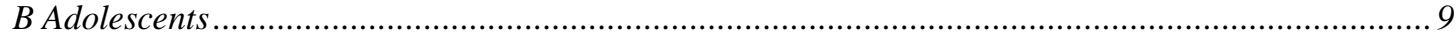

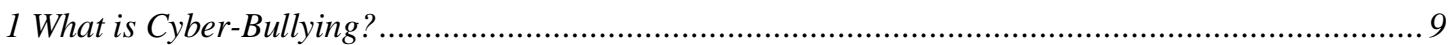

2 What Harm does Cyber-Bullying Cause? …………........................................................... 10

III The Harmful Digital Communications Bill............................................................... 12

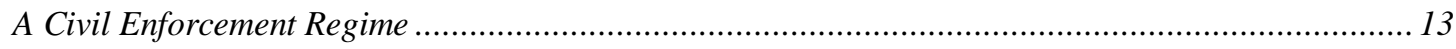

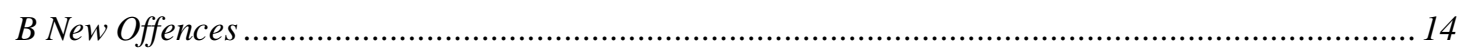

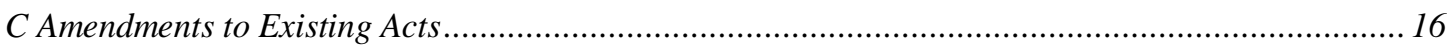

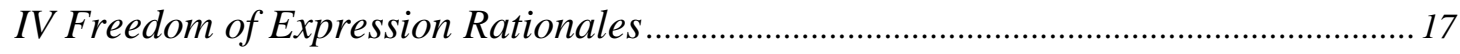

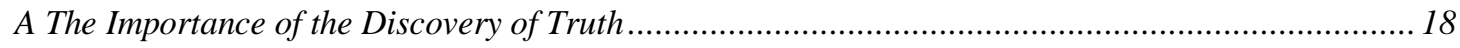

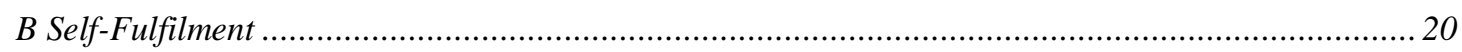

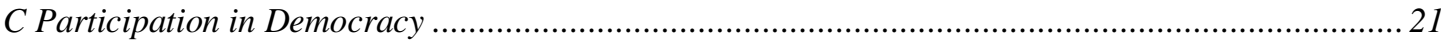

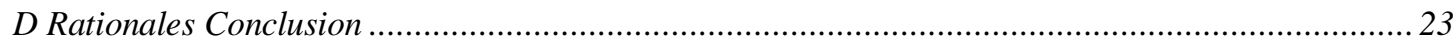

$V$ Freedom of Expression Under the New Zealand Bill of Rights Act 1990.................... 23

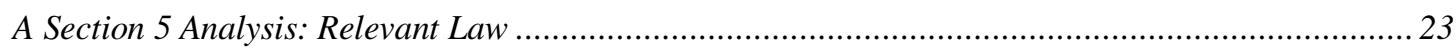

B Does Parliament's Intended Meaning Appear to Limit a Guaranteed Right? .................................. 24

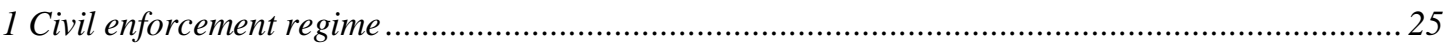

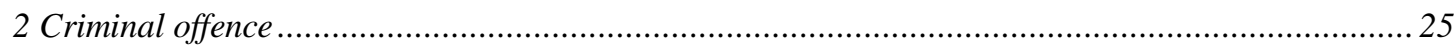

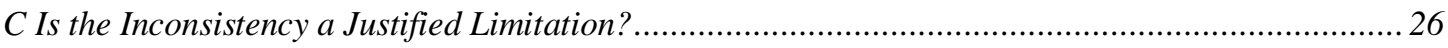

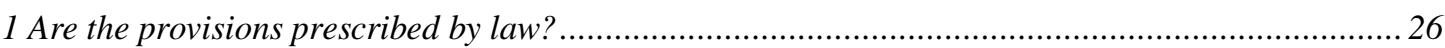

2 Do the provisions serve a sufficiently important purpose? .......................................................... 27

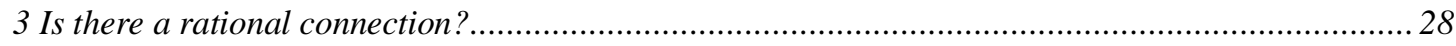

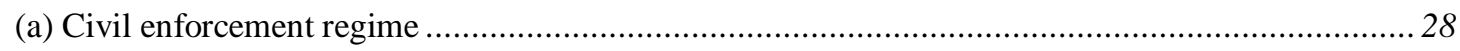

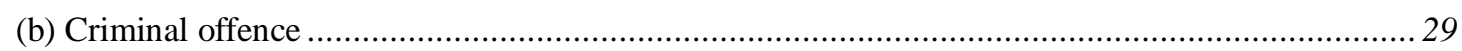

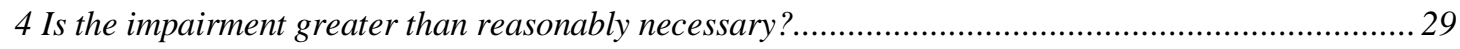

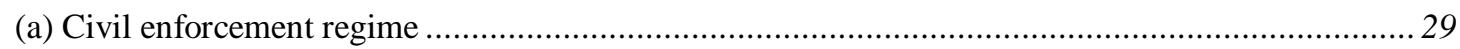

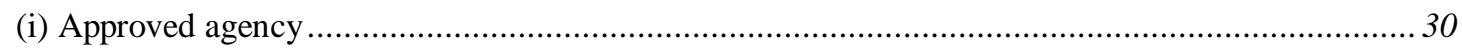

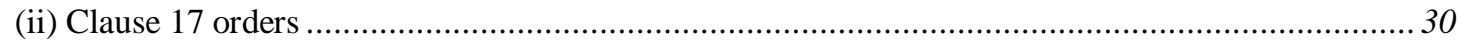

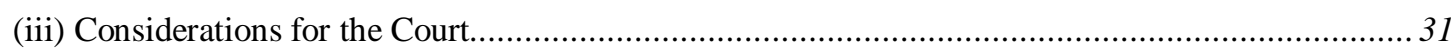

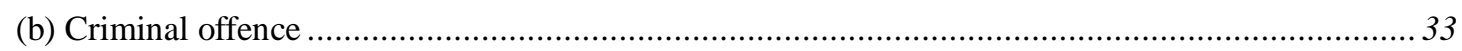

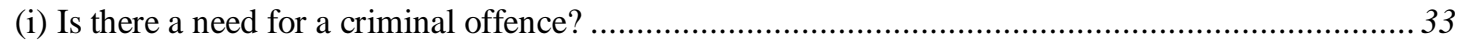

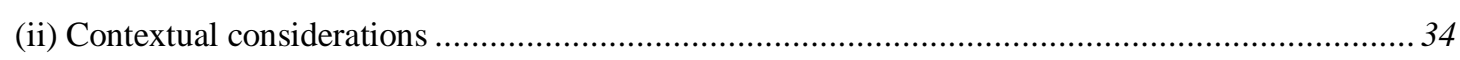

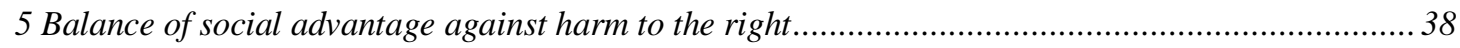




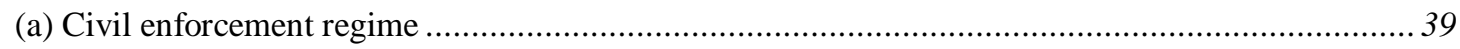

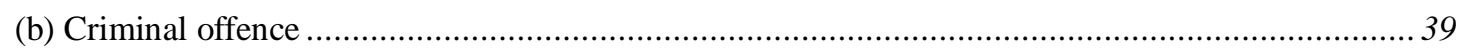

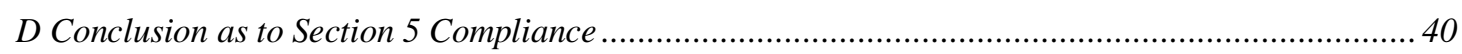

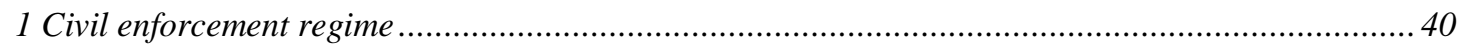

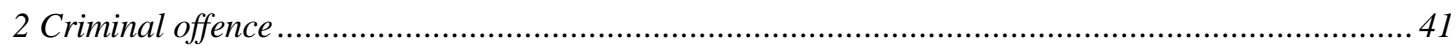

VI Harmful Digital Communication Laws Enacted in Overseas Jurisdictions ............. 41

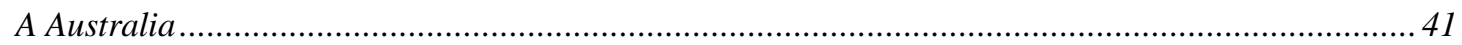

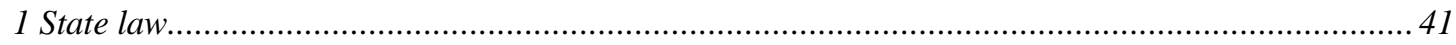

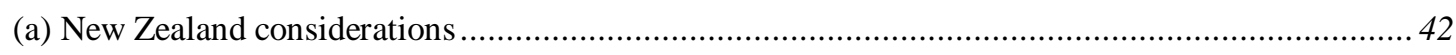

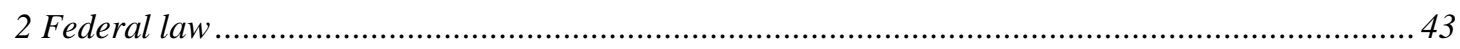

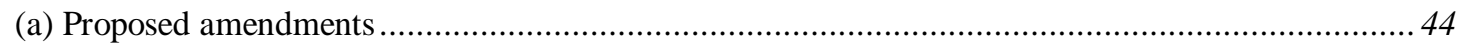

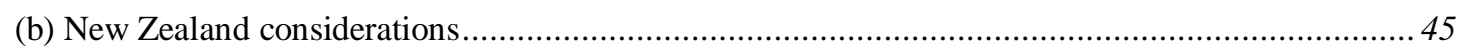

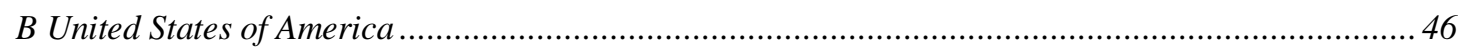

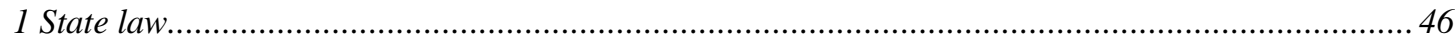

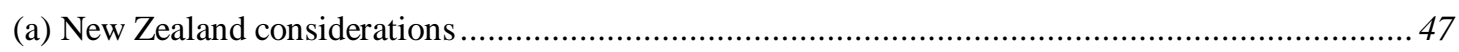

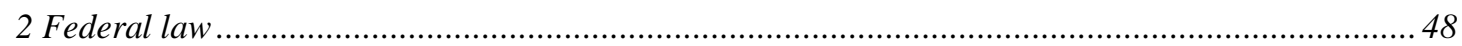

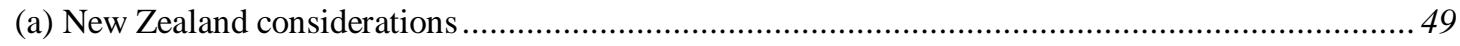

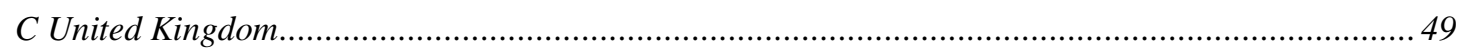

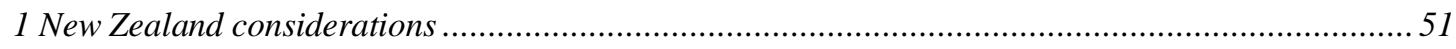

D Conclusion as to Foreign Jurisdictions......................................................................... 51

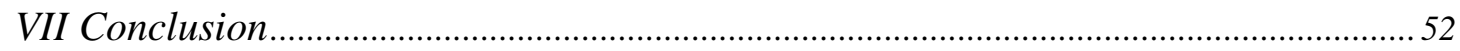

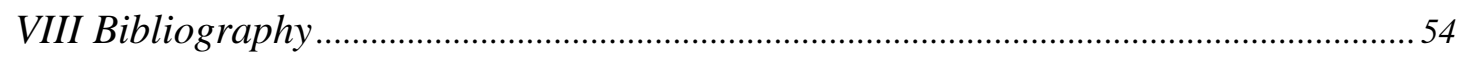




\begin{abstract}
Harmful Digital Communications have become a pervasive and serious problem in New Zealand. The Harmful Digital Communications Bill aims to address this problem in a number of ways. This paper focuses on the civil enforcement regime and the criminal offence of causing harm by posting a digital communication established by the Bill. It considers these aspects of the Bill in light of the right to freedom of expression, and analyses whether they constitute a justified limitation on that right. By applying the New Zealand Bill of Rights Act 1990 section 5 analysis from Hansen $\mathrm{v} \mathrm{R}$, the paper discovers that the civil enforcement regime is a justified limitation, but the new criminal offence is not. The paper concludes that the inclusion of a public interest defence in the offence would allow it to effectively ameliorate the harm caused by online abuse without impinging on freedom of expression more than is reasonably necessary.
\end{abstract}

\title{
Subjects and Topics
}

Harmful Digital Communications

Cyber-Bullying

Freedom of Expression

Demonstrably Justified

\section{Word Court}

The text of this article comprises approximately 14,916 words, excluding abstract, footnotes and bibliography. 


\section{Introduction}

In the months leading up to her death, Charlotte Dawson had been the victim of sustained and vicious online abuse, and had become passionate about campaigning against cyber-bullying as a result. ${ }^{1}$ In February 2014, the Australian based New Zealand television personality committed suicide after a well-publicised battle with depression, and has since become known as New Zealand's most prominent victim of “cyber-bullying". ${ }^{2}$ Charlotte's story also serves as a reminder that online abuse is not simply an adolescent problem, but can be directed at and has deleterious effects on people of all ages. ${ }^{3}$ Friends of Charlotte's created a petition soon after her death, calling for the Australian Government to implement tougher laws targeting abusive digital communications. ${ }^{4}$

Hayley-Ann Fenton was 15 years old when she took her life by ingesting a fatal dose of her father's heart medication in 2009. ${ }^{5}$ The Rotorua teenager had entered into a relationship with Pelesasa Tiumalu, a 27 year old man, who she met while working at McDonalds. After 5 months together, Pelesasa ended their relationship, and resumed his relationship with his estranged wife, Elina. As Pelesasa stood by and watched, Elina sent threatening and abusive text messages to Hayley-Ann from Pelesasa's cell phone, claiming that he did not like Hayley-Ann and that he didn't care whether she killed herself. ${ }^{6}$ Later that night Hayley-Ann was discovered unconscious in her family's bathroom and rushed to hospital, where the following day her parents made the decision to turn off her life support. Coroner Wallace Bain said the overarching cause of Hayley-Ann's death was the "shocking, bullying" text messages from Elina. ${ }^{7}$ Hayley-Ann's death prompted calls for a law change that would deter users of digital communication from sending malicious content. ${ }^{8}$

\footnotetext{
${ }^{1}$ Sam Boyer "Calls go out for "Charlotte's Law" $<$ www.nzherald.co.nz>.

${ }^{2}$ Colin Gavaghan "Cyber-bullying and the law" $<$ https://blogs.otago.ac.nz $>$.

${ }^{3}$ Josh Taylor "Government has no plans for "Charlotte's Law" <

${ }^{4}$ Boyer, above $\mathrm{n} 1$.

${ }^{5}$ Amanda Gillies "Call for cyber bullying law after death" <www.3news.co.nz $>$.

${ }^{6}$ Michael Dickison "News about abusive texts stuns parents of dead girl" $<$ http://www.nzherald.co.nz $>$

${ }^{7}$ Abigail Hartevelt "Call for new cyber bullying laws" $<$ www.nzherald.co.nz $>$.

${ }^{8}$ Gilles, above $\mathrm{n} 5$.
} 
Cases such as these led Prime Minister John Key to call for a "national conversation" on how to reduce bullying in our schools in $2011 .{ }^{9} \mathrm{He}$ commissioned a report on the challenges facing New Zealand adolescents, which considered the impact of digital technology and emphasized the need for the law to reflect the drastically changed environment in which young New Zealanders are now growing up. ${ }^{10}$ The following year, the Law Commission released a ministerial briefing paper entitled Harmful Digital Communications: The Adequacy of the Current Sanctions and Remedies (the ministerial briefing paper). It made recommendations for how to better incorporate harm through digital communications into the law.

The Harmful Digital Communications Bill (the Bill) was drafted in response to the ministerial briefing paper's finding that current laws do not adequately address new forms of harm resulting from digital communications. The Bill suggests a number of alterations, including establishing a new civil enforcement regime, amending existing law relating to communications, and creating a new criminal offence of causing harm by posting a digital communication. ${ }^{11}$ The Bill has been assessed by the Justice and Electoral Committee (the select committee), and is now awaiting its second reading.

While many New Zealanders see the Bill as a positive step, there are also those who think it encroaches too much on freedom of expression. ${ }^{12}$ This paper considers the Bill in light of the right to freedom of expression, and analyses whether it constitutes a justified limitation on that right. The body of this paper is divided into seven parts. Part II considers what constitutes harmful digital communication and "cyberbullying", and the injurious effects online abuse can have on victims. Part III sets out how the Harmful Digital Communications Bill aims to amend the law in this area. Part IV looks at the theoretical rationales underpinning freedom of expression, and assesses how the type of speech targeted by the Bill fits within those rationales. Part

\footnotetext{
${ }^{9}$ New Zealand Law Commission Harmful Digital Communications: The Adequacy of the Current Sanctions and Remedies, ('Harmful Digital Communications') (Wellington, 2012) at [2].

${ }^{10}$ Harmful Digital Communications, above n 9 at [6.5]. This resulted in a report from the Prime Minister's Chief Science Advisor Improving the Transition: Reducing Social and Psychological Morbidity During Adolescence ("PMCSA Report") (Office of the Prime Minister's Science Advisory Committee, May 2011).

${ }^{11}$ Harmful Digital Communications Bill 2013 (168-2).

${ }^{12}$ Tech Liberty "Submission: Harmful Digital Communications Bill"; Google "Submission of Google on the Harmful Digital Communications Bill".
} 
$\mathrm{V}$ of the paper then considers the implications the Bill may have on the right to freedom of expression by applying the New Zealand Bill of Rights Act 1990 (NZBORA) section 5 analysis from Hansen $v R \cdot{ }^{13}$ Part VI compares the Bill with laws targeting online abuse enacted in Australia, the United Kingdom and the United States of America, assessing whether the Bill could be further improved by incorporating aspects of foreign law. Finally, the paper concludes by considering how the Bill could best be amended to effectively ameliorate the harm caused by online abuse without impinging on freedom of expression more than is reasonably necessary.

\section{Harmful Digital Communications: Scope and Effect}

This section discusses the prevalence of harmful digital communications, first within the general population, and then amongst adolescents specifically. It also considers the seriousness of the harm caused by these electronic abuses.

The term "harmful digital communications" will be used throughout this paper to cover the spectrum of behaviours involving the use of digital technology to intentionally cause harm to another person. The term "cyber-bullying" will be reserved for harmful digital communications that occur within the context of adolescent peer relationships.

\section{A General Population}

\section{$1 \quad$ Prevalence of harmful digital communications}

In a submission to the Law Commission, the New Zealand Police noted "existing and potential harms to the public from speech abuses are significant" and that police were dealing with "a growing number of complaints from members of the public who have been intimidated, bullied, harassed and threatened on the internet. ${ }^{14}$ NetSafe, an independent non-profit organization that promotes cyber safety, submitted that on average it was advising 75 people each month who were dealing with some kind of

\footnotetext{
${ }^{13}$ Hansen $v$ R [2007] 3 NZLR 1 (SC).

${ }^{14}$ Submission of New Zealand Police (March 2012) at 3, in Harmful Digital Communications, above $n$ 9, at [2.11].
} 
digital abuse or harassment. ${ }^{15}$ Netsafe approximated half of these cases are in relation to serious online abuses being perpetuated against an adult, and half relate to cyberbullying involving adolescents. ${ }^{16}$ To further assist in assessing the prevalence of the problem, the Law Commission commissioned independent research on the topic, interviewing $750 \mathrm{New}$ Zealanders aged 18-70. Approximately ten percent of those surveyed had "personal experience of harmful speech on the internet", with that number rising to 22 percent of $18-19$ year olds. ${ }^{17}$

This research shows that harmful digital communications currently affect a large number of New Zealanders, and this problem is the cause of growing concern for those who deal with complaints. The research also importantly highlights that harmful digital communications impact adults as well as children. Despite adolescent cyberbullying being the most well known example of online abuse, this harmful behaviour affects people of all ages, and at all stages of life. ${ }^{18}$

\section{Effects of harmful digital communications}

The Law Commission considered the unique nature of digital communications, and pointed to a number of factors that contribute to the distinctive type of harm online abuse can cause. In particular, it focused on the ability of online communicators to adopt anonymous or multiple personae, the extent to which digital communications can reach a victim at any place and time due to the universality of technology, the viral nature of the internet, and the permanence of digital information as key features distinguishing digital abuse from other types of harmful communications. ${ }^{19}$

The Law Commission discussed a number of submissions it received from victims of harmful digital communications describing the difficulties they had experienced. Not only did many of these victims report feeling physically unsafe, they also described how online abuse had contributed to the breakdown of personal and professional relationships, and the loss of their reputations. ${ }^{20}$

\footnotetext{
${ }^{15}$ Harmful Digital Communications, above n 9, at [2.15].

${ }^{16}$ Harmful Digital Communications, above n 9, at [2.15].

${ }^{17}$ Harmful Digital Communications, above n 9 at [2.18].

${ }^{18}$ PMCSA Report, above n 10, at 217.

${ }^{19}$ Harmful Digital Communications at [2.42].

${ }^{20}$ At [2.40].
} 
The large majority of research available on harmful digital communications focuses on the prevalence and effects of cyber-bullying amongst school aged children and adolescents. Bullying in general is a pervasive problem in New Zealand. In the first New Zealand study of its kind, a Victoria University researcher has found that 94 percent of the school staff she surveyed had seen bullying of some kind in their school. ${ }^{21}$ Research carried out by Netsafe estimates that approximately 1 in $5 \mathrm{New}$ Zealand high school students have experienced some form of cyber-bullying or harassment. ${ }^{22}$ While research varies as to exactly how prevalent cyber-bullying actually is, data shows it is likely that at least 15 percent of New Zealand adolescents have been the victim of cyber-bullying at some point. ${ }^{23}$

What is cyber-bullying?

The term "bullying" has countless definitions, and may mean a variety of things to different people based on their experiences. For the purpose of this paper, it is sufficient to refer to the broad meaning given to it by Dan Olweus, who describes bullying as recurrent, intentionally harmful acts that involve a power imbalance between the aggressor(s) and the victim. ${ }^{24}$

Cyber-bullying occurs when a child or adolescent targets another child or adolescent using the internet, digital technologies or mobile phones. ${ }^{25}$ It has been defined as "cruelty to others by sending or posting harmful material or engaging in other forms of social aggression using the internet or other digital technologies." ${ }^{26}$ Cyber-bullying can take the form of many different activities, including posting private photos,

\footnotetext{
${ }^{21}$ Vanessa A Green and others "Bullying in New Zealand Schools: A Final Report" (2013) Victoria University of Wellington at 5.

${ }^{22}$ Harmful Digital Communications, above n 9, at [2.28].

${ }^{23}$ PMCSA Report, above n 10, at 125.

${ }^{24}$ Dan Olweus Bullying at school: What we know and what we can do (Oxford, UK, 1993).

${ }^{25}$ Colleen Barnett "Cyberbullying: A New Frontier and a New Standard; A Survey of and Proposed Changes to State Cyberbullying Statutes” (2009) 27 Quinnipiac L. Rev. 579 at 579.

${ }^{26}$ Benjamin Walther "Cyberbullying: Holding Grownups Liable For Negligent Entrustment" (2012) 49 Hous L Rev 531 at 532.
} 
sending harassing messages by phone or e-mail, or posting offensive comments on a blog or social media website. ${ }^{27}$

Key aspects of traditional bullying and cyber-bullying overlap considerably. ${ }^{28}$ For example the offender's motivation to inflict harm on his or her victims, remains the same in both cases. ${ }^{29}$ The main difference between traditional bullying and cyberbullying is the way the bully is able to continue the harmful acts beyond school premises, and essentially "follow targets into their homes." ${ }^{30}$ Cyber-bullying is far more ubiquitous than other forms of bullying in the lives of those being targeted, and may result in stronger negative outcomes than traditional bullying. ${ }^{31}$

A factor that further exacerbates the effects of cyber-bullying is the difficulty in supervising online behaviour. ${ }^{32}$ While teachers or school administrators are expected to intervene in traditional bullying, there is no clear figure that regulates bullying on the internet. ${ }^{33}$ It has been said that adolescents lose their inhibitions in the absence of central power and clear boundaries. ${ }^{34}$ Additionally, physical distance can allow young people to trivialise their behaviour and the harm it may be causing. ${ }^{35}$

$2 \quad$ What harm does cyber-bullying cause?

Research shows clear evidence of an association between suicide and bullying among children and adolescents. A Canadian report found that victims of bullying exhibit high levels of suicide ideation, and are more likely to have attempted suicide

\footnotetext{
${ }^{27}$ Walther, above n 26, at 532. For a detailed discussion on various types of cyber-bullying see Darryn Cathryn Beckstrom "State Legislation Mandating School Cyberbullying Policies and the Potential Threat to Students' Free Speech Rights" 33 (2008) VT L REV 283 at 290.

${ }^{28}$ Robert Tokunaga "Following you home from school: A critical review and synthesis of research on cyberbullying victimization" (2010) 26 Computers in Human Behavior 277 at 278.

${ }^{29}$ Tokunga, above $\mathrm{n} 28$, at 278.

${ }^{30}$ Tokunga, above $\mathrm{n} 28$, at 278 .

${ }^{31}$ Tokunga, above $\mathrm{n} 28$, at 281.

${ }^{32}$ Dianne L Hoff and Shaheen Shariff "Cyber bullying: Clarifying Legal Boundaries for School Supervision in Cyberspace" (2007) 1 International Journal of Cyber Criminology 76 at 76.

${ }^{33}$ Tokunga, above $\mathrm{n} 28$, at 279.

${ }^{34}$ Hoff and Shariff, above $\mathrm{n} 32$, at 76.

${ }^{35}$ Hoff and Shariff, above n 32, at 76.
} 
compared with non-victims. ${ }^{36}$ Statements made by New Zealand's Chief Coroner, Judge Neil MacLean, reinforce the findings of this report. Judge MacLean has publically supported proposed law changes targeting cyber-bullying, saying that this type of bullying is "often a background factor" in suicides coming before coroners: ${ }^{37}$

We know it's certainly a risk factor for suicide, and we know that adolescents often talk about interpersonal problems when investigators are looking into not necessarily completed suicides but self-harm.

As well as an association with suicidal thoughts and actions, victims of cyberbullying are reported to have lower self-esteem, higher levels of depression, and to experience significant life challenges. ${ }^{38} \mathrm{~A}$ report focusing on the effects of cyberbullying found the disturbances caused by cyber-bullying range from trivial levels of distress and frustration to serious psychosocial and life problems. ${ }^{39}$

In the Human Rights Commission's submission to the select committee on the Bill, it was pointed out that the right to be free from bullying is fundamental to children's right to personal security. ${ }^{40}$ In a media release regarding the bill, Chief Commissioner David Rutherford commented: ${ }^{41}$

There is no difference between the harm caused by bullying in the real or digital worlds. It's not OK to threaten anyone. Bullying - including cyberbullying - is a major human rights issue in New Zealand because it threatens the very right to life.

The Law Commission concluded that the problem of harmful digital communications is sufficiently serious and widespread to justify amendment to New Zealand law.

\footnotetext{
${ }^{36} \mathrm{~A}$ Brunstein Klomek, A Sourander and M Gould "The association of suicide and bullying in childhood to young adulthood: a review of cross-sectional and longitudinal research findings" (2010) 55 Can J Psychiatry 282 at 283.

${ }^{37}$ Simon Collins and Vaimoana Tapaleao "Suicide link in cyber-bullying" < www.nzherald.co.nz>.

${ }^{38}$ Tokunga, above $\mathrm{n} 28$, at 281.

${ }^{39}$ Tokunga, above $\mathrm{n} 28$, at 281 .

${ }^{40}$ Human Rights Commission "Submission to the Justice and Electoral Committee on the Harmful Digital Communications Act 2013".

${ }^{41}$ Human Rights Commission "Harmful Digital Communications Bill" (media release, 20 March 2014) <www.hrc.co.nz>.
} 


\section{The Harmful Digital Communications Bill}

The Harmful Digital Communications Bill was introduced in November 2013, and is largely based on the Law Commission's ministerial briefing paper. ${ }^{42}$ That paper assesses whether the availability of new forms of communication require alterations to New Zealand law. ${ }^{43}$ The Law Commission concluded that some areas of the current law relating to communications have been rendered unsatisfactory by technological and social changes. It found that laws predating the internet are in some cases unable to sufficiently accommodate new forms of communications. ${ }^{44}$ Another issue discussed in the ministerial briefing paper is the lack of accessibility to the relevant law, because of its spread across case law and statute. The Law Commission was concerned with the difficulty this created in allowing people to appreciate the legal implications of their online activities, or to access legal remedies. $^{45}$

The ministerial briefing paper discusses the existing applicable law as it currently stands in relation to threats and intimidation, harassment, sexual matters, incitement, defamation, breach of confidence and privacy. It then sets out how this law applies, or would be likely to apply, in situations involving harmful digital communications. The paper then makes suggestions as to how some areas of law could be changed to better reflect the technological and social changes that have taken place over the last few years. Some of these reforms aim simply to amend laws to make them more easily applicable in the digital environment. ${ }^{46}$ However the Law Commission also proposed the establishment of new offences to address the specific harms caused by certain types of digital communication. ${ }^{47}$ The Bill implements the majority of recommendations made by the ministerial briefing paper, including the establishment of a civil enforcement regime, new criminal offences, and amendments to current

\footnotetext{
${ }^{42}$ Harmful Digital Communications Bill, above n 11, (explanatory note).

${ }^{43}$ Harmful Digital Communications, above n 9, at [4.3].

${ }^{44}$ Harmful Digital Communications, above n 9, at [4.53].

${ }^{45}$ At [4.54].

${ }^{46}$ At [4.55].

${ }^{47}$ At [4.56].
} 
laws. This section gives a brief overview of the Bill, and how it affects law currently in place.

\section{A Civil Enforcement Regime}

The civil enforcement regime established by the Bill aims to provide effective and accessible remedies to victims of harmful digital communications, responses that are proportionate to harm and remedies that are cost effective and quick. ${ }^{48}$ It is intended that this regime will deal with the vast majority of harmful digital communication complaints. ${ }^{49}$ Clause 8 of the Bill provides for initial complaints about harmful digital communications to be made to an "approved agency", which may investigate a complaint and attempt to resolve it by negotiation, mediation, and persuasion. ${ }^{50}$ The approved agency will operate as the first stop for complainants. If a complainant is unsatisfied with the action taken by the approved agency, he or she may then apply for an order from the District Court. ${ }^{51}$

The ministerial briefing paper advises that the already established NGO NetSafe be given formal recognition as the approved agency, responsible for advising complainants and, where appropriate, attempting to achieve a resolution by negotiation, mediation and persuasion. ${ }^{52}$ Whether or not Netsafe will in fact be deemed the approved agency under section 7 is not yet known.

The Bill sets out 10 "communication principles" to guide the court and approved agency. It states that a digital communication should not: ${ }^{.3}$

1. disclose sensitive personal facts about an individual;

2. be threatening, intimidating, or menacing;

3. be grossly offensive to a reasonable person in the complainant's position;

4. be indecent or obscene;

5. be part of a pattern of conduct that constitutes harassment;

\footnotetext{
${ }^{48}$ Harmful Digital Communications Bill, above n 11, (Justice and Electoral Committee Commentary).

${ }^{49}$ Ministry of Justice Harmful Digital Communications Bill - Initial Briefing (6 March 2014) at [11].

${ }^{50}$ Harmful Digital Communications Bill, above n 11, (explanatory note).

${ }^{51}$ Harmful Digital Communications Bill, above n 11, cl 17.

${ }^{52}$ Harmful Digital Communications, above n 9, at [66].

${ }^{53}$ Harmful Digital Communications Bill, above n 11, at cl 6.
} 
6. make a false allegation;

7. contain a matter that is published in breach of confidence;

8. incite or encourage anyone to send a message to a person with the intention of causing harm to that person;

9. incite or encourage another person to commit suicide;

10. denigrate a person by reason of his or her colour, race, ethnic or national origins, religion, gender, sexual orientation, or disability.

Under clause 11(2), a District Court cannot grant an application for an order unless:

(a) it is satisfied that there has been a serious or repeated breach of one or more communication principles, and;

(b) the breach has caused or is likely to cause harm to a person.

The Bill defines harm as "serious emotional distress". ${ }^{54}$ This is intended to be a relatively high threshold, and would not include mere embarrassment, anxiety, worry or outrage; however it is not intended to be so high a threshold as to require a psychiatric or medical assessment. ${ }^{55}$ This is a purely subjective standard, as the civil enforcement regime aims to remedy actual harm and is not intended to be punitive in nature. ${ }^{56}$ Where both requirements are satisfied, a court is able to issue a number of orders against the communicator, including an order to take down material and an order that the defendant cease the conduct concerned. ${ }^{57}$

In some cases, the orders available to the court under the civil enforcement regime apply to both the original communicator of the harmful material, as well as website hosts, ISPs and internet intermediaries. While both categories of orders raise very interesting issues, the discussion in this paper is confined to matters surrounding orders made against the original communicator, and the implications those orders may have on the right to freedom of expression.

\section{B New Offences}

\footnotetext{
${ }^{54}$ Harmful Digital Communications Bill, above n 11, cl 4.

${ }^{55}$ Ministry of Justice, above n 49, at [10].

${ }^{56}$ Harmful Digital Communications, above $\mathrm{n}$ 9, at [5.62].

${ }^{57}$ Harmful Digital Communications Bill, above n 11, cl 17.
} 
Failure to comply with an order made by the District Court under the civil enforcement regime will be made an offence under clause 18 . In the case of a natural person, the offence is punishable by imprisonment for a term not exceeding 6 months or a fine not exceeding $\$ 5,000$. In the case of a body corporate, it is punishable by a fine not exceeding $\$ 20,000 . .^{58}$

Clause 19 of the Bill creates an offence of causing harm by posting a digital communication. This offence was drafted in response to the Law Commission's finding that the criminal law does not adequately address communications that inflict distress or mental harm where it does not relate to fear of physical damage. ${ }^{59}$ The offence is intended to apply in three situations that are currently not criminalised:

1. Where a person is threatened or intimidated and suffers emotional harm, but does not necessarily fear a risk to their physical wellbeing;

2. Where an intimate visual recording, which was made with the consent of the subject, is published without the consent of that person. This is commonly known as "revenge porn", and does not currently fall under the offences relating to intimate visual recordings under the Crimes Act 1961 as those offences only relate to recordings made without consent;

3. Malicious impersonation. Impersonation is currently only criminalised where there is a gain or a loss to another person. ${ }^{60}$

The offence set out in clause 19 is as follows: ${ }^{61}$

(1) A person commits an offence if-

(a) the person posts a digital communication with the intention that it cause harm to a victim; and

(b) posting the communication would cause harm to an ordinary reasonable person in the position of the victim; and (c) posting the communication causes harm to the victim.

\footnotetext{
${ }^{58}$ Harmful Digital Communications Bill, above n 11, cl 18.

${ }^{59}$ Harmful Digital Communications, above $\mathrm{n} 9$, at [4.66].

${ }^{60}$ Ministry of Justice, above n 49 at [22.1].

${ }^{61}$ Clause 19.
} 
(2) In determining whether a post would cause harm, the court may take into account any factors it considers relevant, including-

(a) the extremity of the language used:

(b) the age and characteristics of the victim:

(c) whether the digital communication was anonymous:

(d) whether the digital communication was repeated:

(e) the extent of circulation of the digital communication:

(f) whether the digital communication is true or false:

(g) the context in which the digital communication appeared.

(3) A person who commits an offence against this section is liable on conviction to imprisonment for a term not exceeding 2 years.

(4) In this section, victim means the individual who is the target of a posted digital communication.

This offence will be applicable to persons aged 14 and older. ${ }^{62}$

\section{Amendments to Existing Acts}

The Bill also proposes amendments to existing provisions in order to make them more readily applicable to digital communications. One of these amendments is to section 179 of the Crimes Act 1961, which makes it an offence to incite, counsel or procure a person to commit suicide, if that person actually commits or attempts to commit suicide. ${ }^{63}$ The Bill amends this section by adding an offence of aiding and abetting suicide where suicide or attempting to commit suicide does not result. ${ }^{64}$

The Bill also aims to amend the Harassment Act 1997 by expanding the meaning of "harassment" to include a single continuing act that is carried out over a protracted period. ${ }^{65}$ This is to incorporate offensive material that may be posted and left on a social media site for several weeks or months. ${ }^{66}$ The Harassment Act is also amended

\footnotetext{
${ }^{62}$ Ministry of Justice, above n 49 at 41.

${ }^{63}$ Crimes Act 1961, s 179.

${ }^{64}$ Clause 24.

${ }^{65}$ Clause 26.

${ }^{66}$ Harmful Digital Communications Bill, above n 11, (explanatory note).
} 
to include electronic communications in the definition of specified act, ${ }^{67}$ and by including as a standard condition of a restraining order a condition that, in the case of a continuing act (as defined in section 3 ) the respondent must take reasonable steps to prevent the specified act from continuing. ${ }^{68}$

Section 30 of the Bill proposes to amend section 61 of the Human Rights Act 1993 by including references to the use of electronic communications, so the section will prohibit broadcasts by means of any electronic communication if the broadcast causes racial disharmony. ${ }^{69}$ The Bill also extends section 62 and section 63 of the Human Rights Act by expanding the situations to which the racial harassment and sexual harassment provisions apply. Under the Bill, the section will apply if a person participates in a forum for the exchange of ideas and information. ${ }^{70}$

The current principles 10 and 11 in section 6 of the Privacy Act 1993 limit the way information, collected by an agency for one purpose, is used or distributed for an alternative purpose. An exception to both of these principles is when the agency believes on reasonable grounds that "the source of the information is a publicly available publication" to which the Harmful Digital Communications Bill adds "and that, in the circumstances of the case, it would not be unfair or unreasonable to use the information". ${ }^{71}$

Beyond this brief description of the proposed amendments, this paper will not consider the aspects of the Bill that amend existing laws. While the Bill contains multiple aspects worthy of examination, the focus of the remainder of this paper is on the establishment of the civil enforcement regime and the offence of causing harm by posting a digital communication.

\section{Freedom of Expression Rationales}

Freedom of expression is an important right, and is protected in almost all liberal,

\footnotetext{
${ }^{67}$ Clause 27.

${ }^{68}$ Clause 28.

${ }^{69}$ Clause 30.

${ }^{70}$ Clauses 31 and 32.

${ }^{71}$ Clause 34.
} 
democratic societies. ${ }^{72}$ The right to freedom of expression under the NZBORA gives everyone "the freedom to seek, receive, and impart information and opinions of any kind in any form." ${ }^{73}$ In the case of Moonen v Film and Literature Board, the right was interpreted by the Court of Appeal as being "as wide as the human imagination." ${ }^{74}$ It may include "anything attempting to convey some view or purpose". ${ }^{75}$

Freedom of expression is a complex right, and one that has given rise to a large and highly developed body of jurisprudence. ${ }^{76}$ This section of the paper will discuss three of the most dominant theoretical justifications for the protection of free expression. It will demonstrate that the speech prohibited under the civil enforcement regime and the offence of causing harm by posting a digital communication are not completely compatible with traditional justifications for freedom of expression. Because of this, the limitation on the right imposed by the Bill can be justified on a theoretical basis.

The three major rationales underlying free speech are: ${ }^{77}$

a) The importance of the discovery of truth;

b) Self-fulfilment; and

c) Participation in democracy.

The importance of the discovery of truth is at the core of John Stewart Mill's justification for free speech. ${ }^{78}$ It is best recognised in the famous words of Justice Holmes: "the best test of truth is the power of the thought to get itself accepted in the

\footnotetext{
${ }^{72}$ Alexander Tsesis "Dignity and Speech: The Regulation of Hate Speech in a Democracy" 200944 Wake For L Rev 497 at 521.

${ }^{73}$ New Zealand Bill of Rights Act 1990, s 14.

${ }^{74}$ Moonen v Film and Literature Board of Review [2000] 2 NZLR 9 (CA) at [19] per Tipping J.

${ }^{75}$ Thompson v Police [2013] 1 NZLR 848 at [76].

${ }^{76}$ Andrew Butler and Petra Butler The New Zealand Bill of Rights Act: a commentary (LexisNexis, Wellington, 2012) at [13.1.2].

${ }^{77}$ Claudia Geiringer and Steven Price "Moving From Self-Justification to Demonstrable Justification the Bill of Rights and the Broadcasting Standards Authority" in Jeremy Finn and Steven Todd (eds) Law, Liberty, Legislation: Essays in Honour of John Butler QC (LexisNexis NZ, Wellington, 2008) at 320. See also Hosking v Runting [2005] 1 NZLR 1 at [233] per Tipping J; Brooker v Police [2007] 3 NZLR 91 at [114] per McGrath J.

${ }^{78}$ John Stuart Mill On Liberty (Cambridge University Press, 1959) as cited in Kent Greenawalt "Free Speech Justifications" (1989) 89 Colum L Rev 119 at 130.
} 
competition of the market." ${ }^{, 79}$ This rationale has also become known by the metaphor of a "marketplace of ideas", based on its conception that the validity of new ideas is tested through competition in the market. ${ }^{80}$ It is premised on the notion that truth is a fundamental good, and the exposure of truth is important in the development of society. ${ }^{81}$ According to Mill, even information that is wholly untrue should be protected under this rationale, because its expression causes the reexamination and reinforcement of truth. ${ }^{82}$ This argument is based not on the idea that individuals will always be able to immediately identify what is true and what is false, but rather on the assumption that if a wide variety of views can be expressed in the marketplace, in the long run the truth will become evident. ${ }^{83}$ By restricting digital expression that causes harm, the Bill prima facie conflicts with this theory; preventing that speech from being added to the marketplace of ideas.

The rationale has, however, been subject to criticism by commentators who argue it is overly simplistic. ${ }^{84}$ One problem identified with the "search for truth" theory is the reality of inequality amongst communicators in the marketplace of ideas. ${ }^{85}$ Victims of online abuse often report feeling powerless due to the overwhelming reach of the internet and the fact that others are easily encouraged to partake in similar bullying behaviour. ${ }^{86}$ This may prevent victims from feeling able to communicate their perspective in order to contribute to the marketplace.

The search for truth is only effective if competing ideas are given equal attention and consideration, which is said to infrequently be the case in reality. ${ }^{87}$ Sadurski writes that a "market failure" can occur when participants in the marketplace lack the resources and incentives to investigate the truthfulness of statements made. ${ }^{88}$ They may instead rely on messages that are already socially dominant, and have no

\footnotetext{
${ }^{79}$ Abrams v United States, 250 US 616, 630 (1919) (Holmes J Dissenting) as cited in Wojciech Sadurski Freedom of Speech and Its Limits (Kluwer Academic Publishers, Massachusetts, 1999) at 8.

${ }^{80}$ Juliet Moses "Hate Speech: Competing Rights to Freedom of Expression" (1996) 8 Auckland U L Rev 185 at 191.

${ }^{81}$ Eric Barendt Freedom of Speech (Oxford University Press, Oxford, 1985) at 8.

${ }^{82}$ Greenawalt, above $\mathrm{n} 78$ at 130.

${ }^{83}$ Greenawalt, above n 78, at 131.

${ }^{84}$ Sadurski, above $\mathrm{n} 79$, at 9 .

${ }^{85}$ Greenawalt, above $\mathrm{n} 78$, at 134.

${ }^{86}$ Harmful Digital Communications, above n 9, at [2.42].

${ }^{87}$ Greenawalt, above n 78, at 134 .

${ }^{88}$ Sadurski, above n 79, at 9-10.
} 
motivation to look further. ${ }^{89}$ Where victims of online abuse are not able to communicate effectively in the marketplace, the harmful messages of "bullies" may become overpowering, particularly where they are offered frequently and by multiple people. In this situation, those receiving the information may feel compelled to rely on the harmful statements because they can find no information to the contrary to cause them to examine what they have repeatedly heard. When this happens, the truthfulness of the statements might never be questioned, and a market failure of the type described by Sadurski would occur.

\section{B Self-Fulfilment}

The self-fulfilment rationale theorises that the ability to form opinions and beliefs through public discussion allows personal growth through intellectual and spiritual development. ${ }^{90}$ This principle is based on the idea that speech is a vital way in which individuals express who they really are, and feedback from that expression helps those individuals in their process of self-perception. ${ }^{91}$ The restriction of ideas or opinions a person wishes to explore can be perceived as an affront to that person's sense of dignity. ${ }^{92}$ According to this rationale, the right to freedom of expression exists even where it is contrary to the welfare and development of society. ${ }^{93}$ Under this rationale, the Bill unjustifiably limits the self-expression and therefore the selffulfilment of the perpetrators of harmful digital communications.

The self-fulfilment rationale has, however, also been subject to various criticisms. A particularly relevant objection is that it only applies to speech, and not to other conduct capable of expressing a person's identity, desires, and preferences. Sadurski suggests that in terms of self-fulfilment, speech cannot be distinguished from other types of expression in any meaningful way. ${ }^{94}$ While other harmful acts, such as physical violence or reckless driving, may also be a successful mode of selfexpression, the law places limits on these activities because of the harm they cause to

\footnotetext{
${ }^{89}$ Greenwalt, above n 78, at 134 .

${ }^{90}$ Barendt, above n 81, at 14.

${ }^{91}$ Sadurski, above n 79, at 17.

${ }^{92}$ Greenawalt, above $\mathrm{n} 78$ at 145 .

${ }^{93}$ Barendt, above n 81, at 14.

${ }^{94}$ Sadurski, above n 79, at 18.
} 
others. ${ }^{95}$ Based on this argument, while the law recognises that speech is an important mode of expression worth protecting, some limits on the right to freedom of expression are justified in order to prevent harm to others. Sadurski argues that if the reason to protect free speech is to enable the self-expression of the speaker, then harmful speech must be subject to the same limits as we accept for other modes of expression, "communicative or otherwise." 96 This rationale is therefore not a persuasive argument against the regulation of abusive speech under the Bill, because the harm caused by harmful digital communications justifies reasonable limits on freedom of expression.

\section{Participation in Democracy}

Liberal democracies are dependent on the choices made by citizens. ${ }^{97}$ Free speech contributes to democracy by ensuring those citizens are assisted in grasping significant political truths, which gives meaning to the exercise of democratic rights. ${ }^{98}$ This is said to be the main principle underlying the First Amendment to the United States Constitution, which is based on the idea that "freedom to think as you will and to speak as you think are means indispensible to the discovery and spread of political truth."99 Alexander Meiklejohn argued that citizens have the right to understand political issues in order to participate meaningfully in the functioning of democracy. ${ }^{100}$ Under this rationale, it is inappropriate for government officials to decide which political messages may or may not be heard due to their interest in retaining the favour of the public in order to remain in office. ${ }^{101}$ The democratic rationale for freedom of expression has been relied on in major New Zealand court decisions; such as Lange v Atkinson, where the Privy Council held defamation laws should be limited to prevent the chilling of speech about elected officials. ${ }^{102}$

This rationale is a particularly popular one used to validate the protection of free

\footnotetext{
${ }^{95}$ Sadurski, above n 79, at 18.

${ }^{96}$ Sadurski, above $\mathrm{n} 79$, at 18.

${ }^{97}$ Greenawalt, above n 78, at 145 .

${ }^{98}$ Greenawalt, above n 78, at 145; Alan R Regal "Hate Propaganda: A Reason to Limit Freedom of Speech" 1(984) 49 Sask LR 303 at 307.

${ }^{99}$ Whitney $v$ California (1927) 274 US 357 at 375 per Brandeis J.

${ }^{100}$ Alexander Meiklejohn Free Speech and its Relation to Self-Government, reprinted in Political Freedom: The Constitutional Powers of the People (New York, 1965); Barendt, above n 81 at 20.

${ }^{101}$ Greenawalt, above n 78, at 145.

${ }^{102}$ Lange v Atkinson [2000] 1 NZLR 257 (PC).
} 
speech in modern Western democracies. ${ }^{103}$ It has, however, been criticised for its inability to justify the protection of non-political speech. The crux of the critique is, even if it can be accepted that freedom of speech relating to political issues is necessary in a democracy, it does not follow that democracy also justifies speech on non-political issues being afforded the same protection. ${ }^{104}$ Based on this interpretation, the type of speech the Bill is aimed at prohibiting will most often not be covered by this rationale. The Law Commission recognised the importance of free political speech in its ministerial briefing paper, and indicated that the recommendations it made were not aimed at censorship of this kind of speech, but rather gratuitous personal attacks of a serious nature. ${ }^{105}$ However, as this paper will discuss in greater detail in part $\mathrm{V}$, the Bill may in fact be sufficiently broad to be capable of including political speech where such speech causes the requisite harm.

This critique distinguishing between political and non-political speech has been objected to for a number of reasons. Firstly, it is argued that categorising speech in such a way is not a straightforward task. Differentiating between speech that is of a political nature and speech that is not political will not always be possible. Therefore, any restriction on "non-political" speech might have a chilling effect on all speech due to the uncertainty of what may fall within that restriction. ${ }^{106}$ Another objection, advanced by Meiklejohn, recognises that our ultimate democratic choices are influenced by more than simply political expression. ${ }^{107}$ Meiklejohn argued that free discussion of all topics is important in a democracy, not just discussion of "political" issues. ${ }^{108}$ Based on Meiklejohn's version of the democratic rationale, the restrictions placed on harmful speech in the Bill amount to a limitation of freedom of expression that cannot be justified, because even harmful speech contributes to the democratic choices of the individuals who hear it.

However, the more persuasive argument is that this theory provides a rationale for protection only to political speech, and that regulation of other types of speech should

\footnotetext{
${ }^{103}$ Barendt, above n 81, at 20.

${ }^{104}$ Regal, above n 98 at 308.

105 Harmful Digital Communications, above n 9, at [23].

106 Moses, above n 80, at 192.

${ }^{107}$ Meiklejohn, above n 100 at 44-50.

108 Alexander Meiklejohn "The First Amendment Is an Absolute" (1961) Supreme Court Review 245 at 256 as cited in Sadurski, above n 79 at 21.
} 
be permitted so long as political discussion regarding the necessity of such regulation is not prevented. ${ }^{109}$

\section{Rationales Conclusion}

The above analysis of each of these three rationales highlights their inability to adequately support protection of the type of the speech that aims to be prohibited by the Bill. Therefore the restriction on harmful digital communications can be justified on theoretical grounds. However, the law does protect a general right to freedom of expression in the NZBORA subject to reasonable limitations, and it is thus necessary to also consider whether the restriction can be demonstrably justified on legal grounds.

$V \quad$ Freedom of Expression Under the New Zealand Bill of Rights Act 1990

The NZBORA requires that limitations placed on rights must be demonstrably justified in a free and democratic society. ${ }^{110}$ This section of the paper considers the extent of the limitation placed on the right to freedom of expression by the civil enforcement regime and the criminal offence of causing harm by posting a digital communication. It analyses whether any limitation is able to be demonstrably justified under section 5, applying the test established in case law.

\section{A Section 5 Analysis: Relevant Law}

The right to freedom of expression contained in the NZBORA has been interpreted as widely as possible, as held in Moonen. ${ }^{111}$ The right to freedom of expression can, however, be limited where it is considered necessary to do so. Section 5 of the NZBORA affirms the proposition that rights are not absolute, but can be subject to reasonable limits. ${ }^{112}$ An enactment is still considered to be consistent with the NZBORA if it limits a right or freedom contained in it, so long as the limitation can

\footnotetext{
${ }^{109}$ Barendt, above $\mathrm{n} 81$, at 22.

${ }^{110}$ New Zealand Bill of Rights Act, above n 73, s 5.

${ }^{111}$ Moonen v Film and Literature Board of Review, above n 74 at [19]. Also see discussion at part IV

of this paper.

112 Butler and Butler, above n 76, at 6.5.
} 
be "demonstrably justified in a free and democratic society." 113

The test used to determine whether limitations on rights are demonstrably justified is a proportionality test. The New Zealand approach to proportionality was set out in the case of Hansen $v R$, and originates from the Supreme Court of Canada case of $R v$ Oakes. ${ }^{114}$ The two-stage test as adapted by Tipping $\mathrm{J}$ in Hansen asks:

(1) Does the limiting measure serve a purpose sufficiently important to justify curtailment of the right or freedom?

(2) Secondly,

(a) Is the limiting measure rationally connected with its purpose?

(b) Does the limiting measure impair the right or freedom no more than is reasonably necessary for sufficient achievement of its purpose?

(c) Is the limit in due proportion to the importance of the objective?

In essence, this inquiry is concerned with whether the method used to achieve Parliament's objective is proportionate to its purpose. As Tipping J noted in Moonen, "a sledgehammer should not be used to crack a nut."115

Before applying this test to each of the relevant provisions, Parliament's intended meaning must first be ascertained. It must then be determined whether that intended meaning is in fact apparently inconsistent with a relevant right or freedom. ${ }^{116}$ Tipping $\mathrm{J}$ held this initial exercise should proceed according to the principle "a meaning inconsistent with the rights and freedoms affirmed by the Bill of Rights should not lightly be attributed to Parliament." ${ }^{117}$ However, he stated where an inconsistent meaning is found, the appropriate next step for the court is to consider whether this inconsistency can be demonstrably justified under section $5 .{ }^{118}$

\section{B Does Parliament's Intended Meaning Appear to Limit a Guaranteed Right?}

\footnotetext{
${ }^{113}$ Paul Rishworth and others The New Zealand Bill of Rights (Oxford University Press, Melbourne, 2003) at 138.

${ }^{114} R v$ Oakes [1986] 1 SCR 103 at [138-140] set out in in Hansen $v$, above $\mathrm{n} 13$ at [104], endorsed in Ministry of Health $v$ Atkinson [2012] 3 NZLR 456 (CA) at [143].

115 Moonen v Film and Literature Board of Review, above n 74 at [18].

${ }^{116}$ Hansen $v R$, above $\mathrm{n} 13$, at [89].

${ }^{117}$ Hansen $v R$, above $\mathrm{n} 13$, at [89].

${ }^{118}$ Hansen $v R$, above $\mathrm{n} 13$, at [90].
} 
Parliament's intention can be ascertained by reference to the powers given to the District Court under clause 17 of the Bill. This clause says that where there has been a serious, repeated, or threatened breach of one or more of the communication principles, and the breach has caused or is likely to cause harm to an individual, the District Court may issue a number of orders against a defendant. These are as follows: ${ }^{119}$

(a) an order to take down or disable material:

(b) an order that the defendant cease the conduct concerned:

(c) an order that the defendant not encourage any other persons to engage in similar communications towards the affected individual:

(d) an order that a correction be published:

(e) an order that a right of reply be given to the affected individual:

(f) an order that an apology be published.

Parliament is intending to limit and does limit a communicator's right to impart harmful information. It does this by granting the Court the right to issue orders requiring that material is taken down or that conduct is ceased. When the right to freedom of expression is limited in this way, it is also necessarily limited in terms of the right to seek and receive information. This is because when a person is constrained from imparting information, listeners are prevented from receiving that information.

Freedom of expression is also limited by the Court's ability to order that a correction, right of reply or apology is published. Inherent in the right to freedom of expression is the right not to speak, ${ }^{120}$ and this right is denied when a court compels speech. Therefore, the power given to the District Court to grant these orders is also an apparent limitation to the right to freedom of expression.

\section{Criminal offence}

Parliament's intention in relation to the criminal offence is clear; the purpose of

\footnotetext{
${ }^{119}$ Sub-clause 1.

${ }^{120}$ Butler and Butler, above n 76, at [13.27.1].
} 
clause 19 is to criminalise the posting of a digital communication with the intention to cause harm, where it does in fact cause harm, and where it would have caused harm to the ordinary reasonable person in the position of the victim.

Clause 19 prevents the impartation and receiving of information by criminalising certain types of communication. Clause 19 is therefore also a limitation on the right to freedom of expression.

\section{Is the Inconsistency a Justified Limitation?}

Section 5 stipulates that any limitation on a right or freedom affirmed by the NZBORA must satisfy three criteria. It must be prescribed by law, it must be reasonable, and it must be demonstrably justified in a free and democratic society. ${ }^{121}$

\section{$1 \quad$ Are the provisions prescribed by law?}

"To be prescribed by law, limits must be identifiable and expressed with sufficient precision in an Act of Parliament...be neither ad hoc nor arbitrary and their nature and consequences must be clear, although the consequences need not be foreseeable with absolute certainty." 122

This Bill has not yet been passed into law, and is therefore not currently an Act of Parliament. This paper anticipates however that the Bill will successfully pass through the House and become law. The paper therefore analyses the Bill's NZBORA compatibility in that context.

In a decision subsequent to Hansen, Elias CJ stated that, in order to be characterised as a law, "a rule must be formulated with sufficient precision to enable an individual to regulate his or her conduct accordingly and it must be made accessible to the public." ${ }^{123}$ Both the civil enforcement regime and the clause 19 offence are sufficiently precise in their wording to meet these requirements. Potential communicators can look to the law to determine what type of communication is not permitted under these provisions. This is especially true of the civil enforcement

\footnotetext{
${ }^{121}$ New Zealand Bill of Rights Act, above n 73, s 5

${ }^{122}$ Hansen $v$ R, above $\mathrm{n} 13$ at [180].

${ }^{123}$ Siemer v Solicitor-General [2013] NZSC 68 at [22]; Duff v Communicado Ltd [1996] 2 NZLR 89 at [201] per Blanchard $\mathbf{J}$.
} 
regime, which is particularly comprehensive in its description of unacceptable types of communications through its inclusion of communication principles. The criminal offence is less comprehensive in its drafting, containing only harm requirements and no further information as to the context in which communications might be made. This omission will be discussed further under the proportionality analysis, however, for the purposes of this initial stage of the inquiry the offence is also adequately clear to meet the standard of "prescribed by law."

The court in Hansen considered the reasonableness and justifiability criteria together using the test set out above from the Canadian case of Oakes. ${ }^{124}$ This approach asks whether the limiting measure serves a purpose sufficiently important to justify curtailment of the right or freedom. Once this is established, the test then asks whether the means selected to address the concerns are proportionate to the harm being addressed. ${ }^{125}$

\section{Do the provisions serve a sufficiently important purpose?}

McGrath $\mathrm{J}$ noted that it would be rare for a court to find that an objective of the legislature was a goal without legitimacy. ${ }^{126}$ Deference should be given to Parliament at this stage of the inquiry, which will almost always result in a finding that the concern being addressed is an adequately important one. This stage of the inquiry will usually be rather straightforward, with more in depth consideration occurring in the second part of the Oakes test.

Digital communications have introduced novel forms of harm due to the public nature, reach and longevity of the communications. ${ }^{127}$ The Law Commission paper found that as many as one in ten New Zealanders has personal experience of harmful digital communications. ${ }^{128}$ It also concluded that current legal remedies for such harm are insufficient. ${ }^{129}$ The provisions in question are intended to prevent harm caused to victims of online abuse, or cyber-bullying. These harms, discussed

\footnotetext{
${ }^{124}$ Hansen $v$ R, above $\mathrm{n}$ 13, at [42] per Elisa CJ; [64] per Blanchard J; [103]-[104] per Tipping J; [203][204] per McGrath J, [269] and [272] per Anderson J.

${ }^{125} R v$ Oakes, above n 114.

${ }^{126}$ Hansen $v$ R, above n 13, at [207].

${ }^{127}$ Harmful Digital Communications, above n 9, at [2.66].

${ }^{128}$ Harmful Digital Communications, above n 9, at [38].

${ }^{129}$ Harmful Digital Communications, above n 9, at [3.3].
} 
in part II, include the presence of higher levels of suicide ideation and depression than in non-victims, and other significant issues. Based on research illustrating the close association between cyber-bulling and these types of harms, and taking into account the requirement that deference be given to Parliament at this point, it can be concluded that harmful digital communications are a pressing and substantial concern. Therefore, interference with the right to freedom of expression is warranted in order to reduce or prevent their occurrence.

\section{$3 \quad$ Is there a rational connection?}

The first section of the proportionality analysis asks whether the proposed limit on the relevant right is rationally connected with the objective of the provision. ${ }^{130}$ As in the case of the previous inquiry, the majority in Hansen said that in carrying out this part of the analysis, substantial deference should be given to Parliament. ${ }^{131}$ Therefore, Tipping $\mathrm{J}$ stated that the test for whether a provision is rationally connected to its objective should carry a reasonably low threshold test. ${ }^{132}$

\section{(a) Civil enforcement regime}

The civil enforcement regime is designed to mitigate harm caused to individuals by digital communications by providing victims with a quick and efficient means of redress. ${ }^{133}$ The Bill achieves this by granting the District Court the power to make a number of orders, including orders that harmful material be removed from the internet, and orders aimed at alleviating harm caused by the posting of such material, such as requiring a right of reply or an apology. ${ }^{134}$ Where an order made by the District Court under the civil enforcement regime is not fulfilled, a criminal sanction may be applied under the clause 18 offence of non-compliance with an order. ${ }^{135}$ It is logical to suggest that removal of harmful digital communications from the internet, and in some cases a public apology or opportunity to offer a reply to harmful material, will go some way to mitigate the harms caused to the victims

\footnotetext{
${ }^{130}$ Hansen $v$ R, above $\mathrm{n} 13$, at [64] and [104].

${ }^{131}$ Hansen $v R$, above $\mathrm{n} 13$, at [121] per Tipping $\mathrm{J}$.

132 At [121].

${ }^{133}$ Harmful Digital Communications Bill, above n 11, cl 3(b).

${ }^{134}$ Clause 17.

${ }^{135}$ Clause 18.
} 
of online abuse. Therefore, there is a rational connection between the objective and the proposed limit on the right to freedom of expression.

\section{(b) Criminal Offence}

The question to be answered in terms of clause 19 is whether the criminalisation of particularly harmful online abuse is connected to Parliament's objective. By criminalising harmful digital communications, the Bill aims to deter and prevent such conduct. ${ }^{136}$ Criminalisation has a preventative effect by giving fair warning of the fact of conduct's illegality and the punishment arising from that conduct to those considering engaging in it. ${ }^{137}$ The offence of causing harm by posting a digital communication will inevitably cause some deterrent effect to those who take notice of its existence. It follows then that there is a logical connection between the means and the objective of this provision. Whether or not this particular offence is the appropriate way to achieve this purpose is assessed in the following two inquiries.

\section{$4 \quad$ Is the impairment greater than reasonably necessary?}

The proper application of this portion of the Oakes test has been the subject of much debate. The interpretation of this limb requiring any limit to be the least possible intrusion on the right has been widely criticised as being too strict. ${ }^{138}$ In Hansen, both Tipping and Blanchard JJ expressed the opinion that the test should instead ask whether the limit imposed on the relevant right "is no greater than is reasonably necessary to achieve Parliament's objective." 139 Tipping J said that in practical terms, this requires the court to consider whether another method could have been used to achieve Parliament's objective at a lower cost to the right being limited. ${ }^{140}$ In carrying out this assessment, Tipping $\mathrm{J}$ emphasized it should be recognised that Parliament has some "margin of appreciation" in its choices as to the means chosen to limit a right. ${ }^{141}$

(a) Civil Enforcement Regime

\footnotetext{
${ }^{136}$ Harmful Digital Communications Bill, above n 11, cl 3(a).

${ }^{137}$ Andrew Ashworth and Lucia Zedner "Prevention and Criminalization: Justification and Limits" (2012) 15 New Crim L Rev 542 at 548.

${ }^{138}$ Hanna Wilberg, "The Bill of Rights and Other Enactments" [2007] NZLJ 112 at 117.

${ }^{139}$ Hansen $v$ R, above $\mathrm{n} 13$, at [126] and [79].

${ }^{140}$ Hansen $v R$, above $\mathrm{n} 13$, at [126].

${ }^{141}$ Hansen $v R$, above $\mathrm{n} 13$, at [113]-[119].
} 
(i) Approved agency

Under the civil enforcement regime, an applicant may apply for an order from the District Court only once the approved agency has first considered a complaint about the communication, and had a reasonable opportunity to consider and decide what action (if any) to take. ${ }^{142}$ The approved agency's powers are reasonably limited; it may only use advice, negotiation, mediation and persuasion to resolve complaints. This initial stage of the process does not limit freedom of expression excessively, as it gives the speaker the opportunity to decide for him or herself whether or not to remove the communication in question once the harmful consequences of the communication have been made clear to him or her. The right to refuse to remove the communication or cease the conduct in question is in theory still intact at this stage.

(ii) Clause 17 orders

Where recourse under the approved agency fails, a complainant may apply for an order to be made by the District Court. The District Court is granted much broader powers than the approved agency under the civil enforcement regime, and therefore the power given to the Court to make one or more of the orders set out in clause 17 is a far more significant encroachment on freedom of expression. However, in order to achieve Parliament's objective, it is likely that the availability of some or all of these orders is necessary. This is particularly so in relation to the right of a judge to grant an order requiring a defendant to take down or disable material, or cease the conduct concerned, which would allow the Court to prevent harmful material from being communicated. ${ }^{143}$ While these orders may be seen as a substantial intrusion into the communicator's right to freedom of expression, it is difficult to find alternative methods that could be used to ensure a lesser encroachment on the right while still achieving Parliament's objective. In order for actual harm to be ameliorated, or for a potential harm to be averted, an order to take down or abstain from uploading harmful content is an essential power for the Court to have.

\footnotetext{
${ }^{142}$ Harmful Digital Communications Bill, above n 11, cl 11.

${ }^{143}$ Harmful Digital Communications Bill above n 11, cls 17(1)(a) and 17(1)(b).
} 
An example that highlights the necessity of such an order is when an intimate visual recording is posted without the consent of an applicant who appears in the recording. The most pressing concern for the applicant is that the recording is removed from the internet as quickly as possible so it is not available to be viewed online. No alternative outcome will adequately address the harm to the applicant in this situation. The same reasoning would apply in cases where personal facts have been revealed about a person on social media, or where particularly hurtful comments have been published where others can read them. The viral nature of the internet and the permanence of digital information can increase the impacts of bullying by creating potentially large audiences and allowing information to be used to re-victimise the target each time it is accessed. ${ }^{144}$ Without the ability to order that this material be taken down, or that it not be put online in the first place, the civil enforcement regime cannot achieve its purpose to any great level of success.

Where an order that material be taken down is not justified, the court may make a number of other orders, including that a correction or apology be published, or that a right of reply be given to the affected individual. While these orders do still encroach on freedom of expression by compelling speech, they arguably represent a lesser intrusion on the communicator's rights, and they allow the court to use take down orders only in the most severe and urgent cases.

(iii) Considerations for the Court

The Bill requires there must be harm to a complainant, alongside a serious, repeated or threatened breach of one of the 10 communication principles before an order may be granted. Under the civil enforcement regime, the harm requirement is a purely subjective one. ${ }^{145}$ This is in contrast to the criminal offence, which is based on both subjective harm to the victim and objective harm, in the sense that the ordinary reasonable person in the position of the victim would suffer harm. By requiring that both subjective and objective harm be established before an order may be made under clause 17, the civil enforcement regime would apply to fewer cases and therefore limit freedom of expression to a lesser extent. To amend the civil enforcement regime

\footnotetext{
${ }^{144}$ Harmful Digital Communications, above n 9 at [2.42].

${ }^{145}$ Ministry of Justice, above n 49 at [17].
} 
in this way may be in conflict with its purpose, however, which is not to punish wrongdoers or reflect community standards, but rather to protect those who actually suffer harm. ${ }^{146}$

The Bill sets out a number of considerations the court must take into account before deciding whether an order should be made, and which order is the most appropriate. These are: ${ }^{147}$

(a) the content of the communication and the level of harm caused by it;

(b) the purpose of the communicator, in particular whether the communication was intended to cause harm;

(c) the occasion, context, and subject matter of the communication;

(d) the extent to which the communication has spread beyond the original parties to the communication;

(e) the age and vulnerability of the affected individual;

(f) the truth or falsity of the statement;

(g) whether the communication is in the public interest;

(h) the conduct of the defendant, including any attempt by the defendant to minimise the harm caused;

(i) the conduct of the affected individual or complainant;

(j) the technical and operational practicalities, and the costs, of an order; and

(k) the appropriate individual or other person who should be subject to the order

The Law Commission intended that these would allow the court to have regard to the importance of freedom of expression. ${ }^{148}$ These considerations are important in minimising how greatly the civil enforcement regime limits freedom of expression, as they help to ensure that orders will only be granted where necessary. The considerations also enable the Court to ensure that communications with significant value to society are able to be protected, particularly sub-clauses (c) and (g).

\footnotetext{
${ }^{146}$ Ministry of Justice, above n 49 at [18].

${ }^{147} \mathrm{Cl} 17(4)$.

${ }^{148}$ Harmful Digital Communications, above n 9 at [5.80].
} 
Once all of the clause 17 requirements are established, a court must then determine if a proposed order can be justified in a free and democratic society. ${ }^{149}$ This requirement means that the communicator's right to freedom of expression will be considered in each case, and an order should not be granted unless the limitation on that right can be justified.

In his discussion on deference to parliament, Tipping J described a "target" which parliament's appraisal must not miss in order for a limitation to be acceptable. ${ }^{150}$ While the civil enforcement regime does undeniably limit the right to freedom of expression, the measure chosen by Parliament to enact this limitation "hits" the target. Therefore it is apparent that the limitation it imposes on the right to freedom of expression is not more than is reasonably necessary. There are no realistic alternatives to the regime that could still successfully achieve Parliament's objective.

(b) Criminal Offence

(i) Is there a need for a new criminal offence?

The first consideration under this part of the analysis is whether establishing a criminal offence at all is necessary to achieve the objective set out by parliament. The objective of the provision, reducing harm caused by cyber-bullying and online abuse, could arguably be effectively achieved through the amendment of other criminal offences that pre-date the internet, such as harassment, threatening or blackmail. By extending these provisions to ensure that pre-existing offences apply in a digital context, it would also deal with the unusual double standard created by the offence, which is that only digital communications that cause harm are criminalised. ${ }^{151}$ This means that if a person wrote down on paper an objectively and subjectively harmful statement and physically posted it in a public forum, this act would not be criminalised. However, if the same statement were instead posted online, criminal sanctions would apply. The Law Commission considered whether extension of current laws would be sufficient in achieving the objective, but found that the

\footnotetext{
${ }^{149}$ Harmful Digital Communications Bill, above n 11 at cl 17(5).

${ }^{150}$ Hansen $v$ R, above $\mathrm{n} 13$ at [119].

151 "What's wrong with the Communications (New Media) Bill and can it be fixed?" 2 September 2012 <http://techliberty.org.nz>.
} 
increased and unusual risk caused by digital communications warranted the creation of a new offence. The report states: ${ }^{152}$

The new communication technologies can have effects which are more intrusive and more pervasive, and thus more hurtful, than many other forms of activity. The potential for emotional harm is greater than before. There is a risk that it may lead to self-harm or worse. The prospect is sufficiently worrying to justify extending the law.

This suggests that the establishment of a criminal offence is crucial in carrying out Parliament's objective. Therefore, the remainder of the inquiry under the "minimal impairment" limb will focus on whether the offence as it is currently drafted limits the right to freedom of expression no more than is reasonably necessary.

\section{(ii) Contextual considerations}

The offence set out in clause 19 is much broader in scope than the civil enforcement regime. A judge need not consider any extraneous circumstances outside the elements of the offence, being intention to cause harm, subjective harm to the victim and objective harm to the ordinary reasonable person. While clause 19(2) sets out a variety of factors a court may take into account in deciding whether a digital communication would be likely to cause harm, no other contextual factors must be considered. As a consequence, any type of speech that causes harm and would be expected to cause harm to a reasonable person could be included.

The breadth of this offence means freedom of expression could be limited more than is reasonably necessary in order to address the harms discussed above. For example, in providing no safeguards for context, it is possible that political speech could fall within the offence where communications are so offensive to a politician so as to meet the serious emotional distress threshold. One submission to the select committee on this Bill offered the example of a person taking a photo of a politician receiving a bribe and, shocked at the politician's corruption, posting it to the internet. ${ }^{153}$ It is almost certain that to have one's corrupt activities exposed publically would cause serious emotional distress to the ordinary reasonable person in the position of the

\footnotetext{
${ }^{152}$ Harmful Digital Communications, above n 9, at [4.72].

153 Tech Liberty, above n 12, at 11.
} 
victim. Therefore, if it can be shown that the communicator intended to cause harm to the politician, and harm actually did result, the communicator could be liable to imprisonment for up to 2 years under clause 19, despite the fact that the exposure of corrupt politicians may be of value to society. ${ }^{154}$ The offence could also include artistic expression where it causes the required harm, or communications made about newsworthy incidents, such as a court case, or an accident or natural disaster, even where it may be in the public interest for these types of expression to be made. Enhanced specificity regarding how the offence will apply in a variety of contexts could be included in clause 19 in order to ensure the offence is not cast too wide.

A possible amendment to ensure greater clarification would be to extend the application of the clause 6 communication principles, set out above in part III, to the criminal offence. These principles currently only apply to complaints under the civil enforcement regime, and a serious, repeated or threatened breach of one or more of the principles must occur before an order may be made by the court. The offence in clause 19 contains no such requirement, and the principles are not incorporated into the criminal law components of the Bill at all. If clause 19 also necessitated a breach of one or more of the clause 6 principles, the offence would then apply only to specific circumstances in which harmful digital communications were sent or posted. ${ }^{155}$ This addition would assist to ensure minimal interference with the right to freedom of expression.

Another possible method to reduce the friction between freedom of expression and the aim of the offence would be to include in the provision a list of specific contexts in which the offence will not apply, such as when communications are political or artistic. In the Canadian case of Vancouver City v Zhang, the Court of Appeal found that a general prohibition on the erection of structures without the city's prior consent was not constitutionally valid. ${ }^{156}$ In order for this provision to meet the "minimal impairment" limb under the Oakes test, it was found that a policy permitting the regulated use of a structure for political expression should have been included. ${ }^{157}$ Using this reasoning, a list excluding certain contexts may be adequate to ensure the

\footnotetext{
154 Tech Liberty, above 12, at 11.

${ }^{155}$ Steven Price "Submission on Harmful Digital Communications Bill".

${ }^{156}$ Vancouver (Cil) v Zhang 2010 BCCA450 at [67].

${ }^{157}$ Vancouver (Cil) v Zhang, above n 156, at [67].
} 
reach of the offence impinges on freedom of expression to a lesser extent. Including such a list would also help in ensuring the offence is drafted with sufficient clarity. Having an offence that is adequately clear as to what behaviour it criminalises is of particular importance for the average New Zealander who has limited access to legal advice, but who uses digital communications regularly. ${ }^{158}$

Both of these approaches have possible advantages and disadvantages. The inclusion of the communication principles in the offence would limit the context in which the offence may be breached, however, the principles would not make a significant difference to the offence in terms of speech that the law may wish to protect. Some of the principles are very general, such as principle 2, which states that a communication should not be threatening, intimidating or menacing. This principle could conceivably cover a wide range of communications, and does not limit the context beyond the harm requirements already set out in clause 19. A list of contexts in which the offence will not apply would go further in limiting the offence's encroachment into freedom of expression. However, it is likely that a list of this kind goes rather too far, and may work to prevent the offence from achieving Parliament's objective. While this approach may have the advantage of added certainty, it would limit the courts' ability to inquire into whether the harm caused by a communication was so severe as to warrant criminalisation, regardless of the context in which it was made. The main objective of the offence is to address the harm caused in cases of seriously distressing digital communications. ${ }^{159}$ While there should be some mechanism empowering the District Court to declare that the public interest in allowing a communication to be made outweighs the harm caused, in order to properly fulfil Parliament's objective it is important that the Court has some flexibility in the other direction also.

In light of this, a preferable alternative may be to incorporate a general public interest element into the offence. In essence, public interest may be able to justify the communication of harmful speech, even where it meets the requirements under clause 19. The inclusion of a public interest defence would give the court the discretion to

\footnotetext{
158 Jacob H Rowbottom “To Rant, Vent and Converse: Protecting Low Level Digital Speech” (2012) 71 CLJ 355 at 375.

${ }^{159}$ Harmful Digital Communications, above n 9, at [4.57].
} 
find that such communications should not be criminalised, despite the harm they may cause.

An example of such a defence can be found in the Crimes Act 1961 at section 124, which criminalises the distribution or exhibition of indecent matter. Section 124(2) states: "It is a defence to a charge under this section to prove that the public good was served by the acts alleged to have been done." ${ }^{160}$ Another New Zealand example of a public interest defence in a criminal law context relates to the now repealed offence of criminal libel. The previous section 211 of the Crimes Act 1961 stated "criminal libel is matter published without lawful justification or excuse, either designed to insult any person or likely to injure his reputation..."161 Section 214 provided for a "plea of justification" for this offence, which said "every person accused of publishing a criminal libel may plead...(b) that it was for the public benefit that the matters charged should, if true, be published in the manner in which and at the time when they were published."162

These sections provide practical examples of a how a public interest defence could be incorporated into a communication-based offence. Clause 19 could contain a sub clause providing that, notwithstanding that the conduct amounts to a breach of section 19(1), it will be a defence if the defendant can prove that it was within the public interest that the digital communication was made. Under the rules of evidence, this defence element would have to be proved by the defendant on the balance of probabilities. ${ }^{163}$

The inclusion of a public interest defence in clause 19 would be preferable to the enactment of the offence as it is currently drafted. Such a defence allows for some protection of expression that is in the public interest, but does not create rigid categories of speech excepted from the offence. The second question that must be asked under the minimal impairment inquiry is whether the inclusion of a public interest defence still allows for Parliament's objective of preventing and deterring

\footnotetext{
${ }^{160}$ Crimes Act 1961, s 124(2).

${ }^{161}$ Crimes Act, above n 160, at s 211 (repealed).

162 Crimes Act, above n 160, at s 214 (repealed).

${ }^{163}$ Elisabeth McDonald Principles of Evidence in Criminal Cases (Thomson Reuters, Wellington, 2012) at 23.
} 
harmful digital communications to be achieved. It is my submission that a public interest defence would not prevent the offence from achieving Parliament's purpose, as it would still allow for the criminalisation of gratuitously insulting communication. As the addition of a public interest defence still allows for Parliament's objective to be achieved, it follows that the offence in its current form impairs the right to freedom of expression to a greater extent than is reasonably necessary. It therefore misses Tipping J's target of discretion afforded to parliament.

\section{Balance of social advantage against harm to the right}

This limb of the test considers whether the benefits to society outweigh the harm done to an individual right or freedom. ${ }^{164}$ At the heart of this inquiry is the idea that "in each case, the loss to free speech ought not to be greater than the gain for the competing rights and interests served by the speech-limiting law." ${ }^{165}$ Hanna Wilberg writes that one must balance, on one hand the importance of the right in the relevant context and the severity of the limit on that right, and on the other hand the importance of the objective and the effectiveness of the limit in serving the objective. $^{166}$

Freedom of expression is unarguably an important right in a free and democratic society, ${ }^{167}$ however not all speech is considered equal in terms of the value it holds. ${ }^{168}$ In considering the importance of a particular type of expression, it is helpful to consider its value to determine the strength of protection that should be afforded speech of that value. ${ }^{169}$ Political speech is generally considered to be of the highest value, because it falls most clearly within the rationales justifying free speech discussed above. ${ }^{170}$ The types of speech that have commonly been considered to be of low value to society include pornography and obscenity, revelations of personal facts, and personal abuse unconnected to an important issue. ${ }^{171}$ Following this approach,

\footnotetext{
${ }^{164}$ Hansen $v R$ above $\mathrm{n}$ 13, at [132] per Tipping $\mathrm{J}$.

165 Geiringer and Price, above n 77, at 319.

166 Wilberg, above n 138 at 119. See also Richardson J's approach in Ministry of Transport v Noort [1992] 3 NZLR 260 (CA) at 139.

${ }^{167} R v$ Secretary of State for the Home Department [2000] 2 AC 115 (HL) at 126; Hosking v Runting [2005] 1 NZLR 1 (CA) at [178].

168 Geiringer and Price, above n 77, at 322.

${ }^{169}$ Rowbottom, above n 158 , at 366.

${ }^{170}$ Campbell v MGN Ltd [2004] 2 AC 457 (HL) at [148].

${ }^{171}$ Geiringer and Price, above n 77, at 322.
} 
digital communications relating to political matters should be more carefully protected than speech containing personal insults with the purpose of causing emotional harm. Of course, where the line exists between the two may not always be clear, and distinguishing these types of speech from each other would be an important function of the Court in applying the provisions of the Harmful Digital Communications Bill.

(a) Civil enforcement regime

The civil enforcement regime confers an important benefit to society in that it exists to quickly address the harm caused by digital communications. By allowing the District Court to make various orders, the regime has the potential to be very effective in serving Parliament's objective of preventing and mitigating that harm. As discussed in part IV above, protection of the type of speech targeted by the regime is not easily justified by the traditional rationales for freedom of expression. It is speech that can make victims feel powerless and unable to contribute to the marketplace of ideas, and it is not clearly justified under the self-fulfilment principle due to the harm it causes. The factors a judge must consider before making an order under clause 17(4) operate to ensure that political speech and other communications that are in the public interest are protected, and therefore the argument from democracy is not readily applicable to the speech being impacted. The clause 17 orders undoubtedly encroach on the right to freedom of expression. However, because they will work only to limit low value speech, the encroachment is not so significant as to outweigh the social benefit of the civil enforcement regime.

(b) Criminal offence

A criminal penalty is a substantial fetter on free speech - expressing condemnation of the action as a wrong against society. ${ }^{172}$ To criminalise some types of speech is to limit the right to freedom of expression significantly. The suggested maximum penalty for this offence was increased at the select committee stage from a term of imprisonment not exceeding 3 months to a term not exceeding 2 years. This is a severe consequence and will undoubtedly cause a chilling effect on online expression assuming the Bill is made law. However, as discussed above, the harm caused by

${ }^{172}$ Harmful Digital Communications, above n 9, at [4.24]. 
online abuse can be serious and long lasting for many victims, and the consequences can be tragic. Implementation of an effective method of preventing and deterring harmful digital communications is an important social objective.

Although the creation of an offence has been satisfactorily justified, it is not clear that clause 19 impairs the right to freedom of expression only so far as is reasonably necessary. Whether the limitation it imposes on freedom of expression is unduly harsh will depend on how the law is applied. If the offence is used only to criminalise very harmful speech of the lowest value, such as personal insults or the posting of intimate photographs without consent, the limitation is likely to be justified. However, it is not clear that this is the only speech to which the offence will apply. The main issue with clause 19 is the lack of flexibility for the court in protecting harmful digital communications in certain contexts that do justify protection. The clause is not adequately specific as to which contextual factors may be relevant for criminalisation. ${ }^{173}$ The substantial penalty for a breach of clause 19 means that discretion should be given to the court to find that a communication, although harmful in the way the act requires, is within the public interest, and should therefore not be criminalised. The inclusion of a public interest defence would be an appropriate way to ensure the benefit to society is not outweighed by the harm done to the right to freedom of expression.

\section{D $\quad$ Conclusion as to section 5 compliance}

\section{$1 \quad$ Civil enforcement regime}

The civil enforcement regime does limit the right to freedom of expression. It allows the District Court to make a number of orders that infringe upon a communicator's right to digitally send and upload harmful material. This section has argued, however, that these orders are not so rights infringing as to be a disproportionate response to the harms being addressed. As there is no practical alternative to the civil enforcement regime that would allow for the objective of preventing and mitigating harm to be achieved, the regime is a demonstrably justified limitation under section 5 of the NZBORA.

\footnotetext{
173 Price, above n 155.
} 
While the creation of an offence to address egregious communication harms is justified, clause 19 is not specific enough regarding which contextual factors may render communications criminal. Therefore, the limit it places on freedom of expression is greater than reasonably necessary to achieve Parliament's objective. In order to ensure communications that meaningfully serve the public interest are not criminalised, a public interest defence should be incorporated into clause 19. This would allow a judge to retain some discretion as to whether a communication contributes sufficient value to society to warrant protection, despite its harmful effects to a victim. As it currently stands, the social advantage the offence provides is outweighed by the harm is causes to the right to freedom of expression.

\section{Harmful Digital Communications Laws Enacted in Overseas}

\section{Jurisdictions}

In an analysis of the appropriateness of proposed legislation, it is helpful to examine laws enacted in other jurisdictions in an attempt to remedy the same or similar harms. This section will consider laws addressing harmful digital communications in Australia, the United States of America and the United Kingdom in order to gain insight into how online abuse has been dealt with in similar but varying constitutional environments. It will analyse whether any aspects of these foreign laws should be incorporated into the New Zealand Bill in order to make it more effective in achieving its objective.

\section{A Australia \\ $1 \quad$ State law}

The only state-level legislation in Australia relevant to harmful digital communications is a specific cyber-bullying provision enacted in New South Wales. Under section 60E of the Crimes Act 1900 (NSW), it is an offence where a person 
'assaults, stalks, harasses or intimidates' any school staff or student while attending the school. ${ }^{174}$ None of the terms 'assault', 'stalk', 'harass' or 'intimidate' are specifically defined, but on their natural meaning would include cyber-bullying. ${ }^{175}$

This section aims to prevent bullying, but is limited in its inclusion of only staff and students while 'attending the school', which is defined in s $60 \mathrm{D}(2)$ as follows:

(a) while the student or member of staff is on school premises for the purposes of school work or duty (even if not engaged in school work or duty at the time), or

(b) while the student or member of staff is on school premises for the purposes of before school or after school child care, or

(c) while entering or leaving school premises in connection with school work or duty or before school or after school care.

This limitation is significant, because it prevents the offence from including cyberbullying that occurs while the target is anywhere other than on school premises. ${ }^{176}$ While this section may go some way towards deterring students from bullying, it is not broad enough to truly target the harm that cyber-bullying causes due to its invasive reach into the homes of victims.

(a) New Zealand considerations

Legislation criminalising only conduct occurring on school premises is not adequate to address the concerns set out by the New Zealand Law Commission. A very narrow approach of this kind would not be a suitable option for New Zealand to pursue in its attempt to reduce harmful digital communications, as the ministerial briefing paper demonstrated the wide reach of online abuse to people of all ages and in all stages of life.

\section{$2 \quad$ Federal law}

\footnotetext{
${ }^{174}$ Crimes Act 1900 (NSW), s 60E.

175 Des Butler, Sally Kift and Marilyn Campbell "Cyber bullying in Schools and the Law: Is There an Effective Means of Addressing the Power Imbalance?” (2009) 16 Murdoch University Electronic Journal of Law 84 at 89.

${ }^{176}$ Butler, Kift and Campbell, above n 175, at 89.
} 
Australia currently has no federal law enacted specifically to target cyber-bullying, however under section 474.17 of the Commonwealth Criminal Code Act 1995, it is an offence to use a carriage service to menace, harass or cause offence. ${ }^{177}$ The maximum penalty for this offence is 3 years imprisonment. ${ }^{178}$ While the requirement that a carriage service be used to "cause offence" potentially sets a relatively low threshold, this offence has been interpreted as only applying to severe cases of offensiveness. The most widely known case in which this offence has been applied is that of Bradley Hampson,. ${ }^{179}$ Hampson, posted a number of objectionable and sexualized comments on Facebook pages created as tributes to two Queensland children who had been murdered. Among other things, Hampson posted digitally altered photographs of the children placing them in sexual contexts. In one photo, Hampson is said to have posted a photograph of one victim with a penis drawn near her mouth alongside messages including "Woot I'm Dead" and "Had It Coming." ${ }^{180}$ Judge Kerry O'Brien described Hampson's actions as "depraved", and sentenced him to 3 years in prison, but ordered he be released after 12 months. ${ }^{181}$

The offence was also found to apply in the case of Crowther $v$ Sala ${ }^{182}$ Mrs Crowther had been in a long-running dispute with the State of Queensland regarding air pollution near her home. ${ }^{183}$ The dispute escalated until Mrs Crowther eventually called an employee at the Department of Employment and Training and, using explicit language, claimed that she would shoot everyone at the Department. ${ }^{184} \mathrm{Mrs}$ Crowther's submission that the statements were merely "hyperbole" and "Australian colloquialisms" that would not be taken to be menacing by the ordinary listener were rejected by the Queensland Court of Appeal, which found that the offence was indeed made out. $^{185}$

\footnotetext{
177 Commonwealth Criminal Code Act 1995 (Cth), s 474.17.

178 Section 474.17.

$179 R$ v Hampson [2011] QCA 132. See also Commonwealth Director of Public Prosecutions "Case Report - Bradley Paul Hampson" <www.cdpp.gov.au>.

180 Tony Kiem “Facebook troll Bradley Paul Hampson jailed for posting child porn on tribute pages for dead children" (March 25, 2011) <www.couriermail.com.au>.

181 Kiem, above n 180.

182 Crowther v Sala 170 A Crim R 389 [2008] 1 Qd R 127.

183 Crowther $v$ Sala, above n 182, at [36].

${ }^{184}$ Crowther v Sala, above n 182, at [38].

${ }^{185}$ At [11] and [29].
} 
An example of where this offence was found not to apply was in the case of Danziel McNamara, who sent 15 text messages over two weeks to a former friend. These texts contained various derogatory comments, including calling the victim a "fat loser". A judge in an Ipswich Magistrates Court in 2010 found that 47 year old McNamara should not be convicted under section 474.17. Despite the judge describing the messages as "nasty stuff", he ultimately found that the case was not serious enough in comparison with others charged under the offence to warrant a conviction. ${ }^{186}$

(a) Proposed amendments

On 22 January 2014, the Australian Department of Communications released a discussion paper to assist in providing advice to the Government to enhance online safety for children. ${ }^{187}$ This discussion paper sets out a number of possible measures the Government may take to help combat cyber-bullying in Australia, drawing heavily from New Zealand's Harmful Digital Communications Bill in its suggestions.

The Department of Communications looked at existing Commonwealth legislation to determine how best to achieve the Government's objectives. It found that, while laws such as section 474.17 may already cover cyber-bullying in practice, the language of this provision may be difficult for young people to understand. Specifically, the paper found that most people would be unlikely to know what the term 'carriage service' means. ${ }^{188}$ The discussion paper considered three possible approaches to this accessibility problem. Firstly, it suggested raising awareness of the existence of these offences and their meanings through education about the current law. ${ }^{189}$ Secondly, it considered whether a separate cyber-bullying offence covering only wrongdoing involving minors could be enacted to sit alongside section $474.17 .{ }^{190}$ Further, the report considered whether lesser penalties, including counseling, restorative justice, and community-based orders would be suitable for such an offence. Thirdly, the paper

\footnotetext{
186 "Bond for abuse texts to friend" (11 December 2010) <www.qt.com.au>.

187 Australian Department of Communications Enhancing Online Safety for Children: Public consultation on key election commitments ('Enhancing Online Safety for Children') (January 2014).

188 At 20.

189 At 22.

190 At 22.
} 
suggested the creation of a separate civil enforcement regime to deal with cyberbullying modeled on the New Zealand 'approved agency' approach. ${ }^{191}$ The discussion paper cited New Zealand's proposed establishment of an approved agency as an example of an accessible and centralised point of contact to deal with online safety. ${ }^{192}$

(b) New Zealand considerations

A number of the law changes suggested in the Australian Department of Communications' report closely resemble the civil enforcement regime set out in Harmful Digital Communications Bill, albeit with a few modifications. One significant difference discussed above is the suggestion that a new offence be enacted to sit alongside the current section 474.17 , which would be applicable only to minors. This is an interesting approach to the question of how best to criminalise harmful digital communications involving young people. It may be that establishing different types of penalties depending on the age of the offender is an appropriate method to consider in the New Zealand context. In terms of what the Harmful Digital Communications Bill is aiming to achieve with the criminal offence, however, this may not be suitable. Parliament's intention is to reduce instances of serious harm. Cyber-bullying amongst adolescents is the most prevalent type of harmful digital communications. Establishing a separate, lesser offence for adolescents will decrease the deterrent effect criminalisation aims to have. The age of the offender will be taken into account at sentencing stage, at which time restorative justice will also be available in New Zealand. ${ }^{193}$ While establishing a separate offence for minors would decrease the limitation on freedom of expression currently posed by clause 19, the detrimental effect it would have on the ability of the offence to achieve Parliament's objective outweighs the freedom of expression benefit.

B $\quad$ United States of America

$1 \quad$ State law

\footnotetext{
191 At 23.

192 At 5.

${ }^{193}$ Sentencing Act 2002, ss 8(j) and 9(2)(a).
} 
Anti-bullying laws have been enacted in every American state with the exception of Montana. ${ }^{194}$ Unlike the New Zealand Bill, most of these laws only target instances of minors bullying other minors, and do not include harmful digital communications made between adults. ${ }^{195}$ The majority of these states have specifically included the terms "cyber-bullying" or "digital harassment" in their bullying legislation, to ensure that this type of bullying is caught within the provisions. ${ }^{196}$ Without exception, each of these state-level bullying laws requires schools to put in place an anti-bullying policy. ${ }^{197}$ While 44 of the states include a school sanction in their laws, only 14 of these laws allow for a criminal sanction. ${ }^{198}$

At least one of these laws containing a criminal sanction has come under scrutiny for its constitutionality. In Albany, New York, a statute defined cyber-bullying as electronic acts amounting to: ${ }^{199}$ "taunting; threatening; intimidating; insulting; tormenting; humiliating; disseminating embarrassing or sexually explicit photographs; disseminating private, personal, false or sexual information; or sending hate mail" where there was an intention to "harass, annoy, threaten, abuse, taunt, intimidate, torment, humiliate, or otherwise inflict significant emotional harm on another person." Under this Act, knowingly engaging in this behaviour was punishable by up to a year in jail or a $\$ 1000$ fine. ${ }^{200}$

In the New York State Court of Appeal, the first person charged under this offence, 15 year old Marquan Mackey-Meggs, argued the cyber-bullying law unconstitutional. $^{201}$ The Court found that the statute was poorly drafted, which led to it being overbroad and vague. Because of this, the Court ruled the legislation breached

\footnotetext{
${ }^{194}$ For a current list of states with laws relating to cyberbullying, see Sameer Hinduja and Justin Patchin "Description of State Cyberbullying Laws and Model Policies" (2014)

<www.cyberbullying.us>.

195 Hinduja and Patchin, above n 194.

${ }^{196}$ Hinduja and Patchin, above n 194.

${ }^{197}$ Hinduja and Patchin, above n 194.

${ }^{198}$ Hinduja and Patchin, above n 194.

${ }^{199}$ Albany County Local Law No. 11 of 2010, s 1, enacted under the Dignity for All Students Act (2010) (NY).

200 Albany County Local Law No. 11 of 2010, above n 199, s 1.

${ }^{201}$ The People v Marquan M (2014) NY Ct App 139 at [5]. See also Melissa Hale-Spencer "State's Top Court questions Efficacy of Cyberbullying Law" (6 June 2014) <www.altamontenterprise.com>.
} 
the Free Speech clause of the First Amendment, and was therefore invalid. ${ }^{202}$ It is important to note that this decision does not amount to confirmation that cyberbullying legislation is wholly unconstitutional in the United States. Rather, it supports the proposition that precise drafting is necessary to avoid a breach of the First Amendment. The Court stated: ${ }^{203}$

Cyberbullying is not conceptually immune from government regulation, so we may assume, for the purposes of this case, that the First Amendment permits the prohibition of cyberbullying directed at children, depending on how that activity is defined.

\section{(a) New Zealand considerations}

As with the NSW cyber-bullying law, American state level laws address only the harms caused by cyber-bullying occurring between minors. Aligned with the objective of limiting such harms, each of the anti-bullying laws enacted by state legislatures requires schools to put an anti-bullying policy in place. This approach does not accord with the aims of the New Zealand Law Commission, which stated in their ministerial briefing paper that the new laws proposed are intended to apply to all people of ages, and no specific provisions aimed at school involvement are included. New Zealand's Education Act 1989 does in fact already require schools to provide a safe physical and emotional environment for the children in the school's care, which would include having systems in place to prevent bullying of any kind. ${ }^{204}$ The Harmful Digital Communications Bill intends to target the harm caused to victims of any age, and does not delve into the issue of schools' bullying policies, so is fundamentally different from the focus of the various cyber-bullying laws enacted in the American states.

The New York law declared unconstitutional by the New York State Court of Appeal sets out a threshold for harm that is significantly lower than the Harmful Digital Communications Bill's requirement of serious emotional distress. In a New Zealand

\footnotetext{
${ }^{202}$ The People v Marquan M, above n 201 at [15]

${ }^{203}$ The People v Marquan M, above n 201 at [8].

${ }^{204}$ Education Act 1989, s 60A(1)(c).
} 
context, it is unlikely that a provision of this kind would be passed due to the NZBORA section 7 requirement that the Attorney-General shall, when a Bill is introduced to the House, bring to the House's attention any provision which appears to be inconsistent with any of the rights and freedoms contained in NZBORA. ${ }^{205}$ The excessive breadth of the provision recognised by the New York State Court of Appeal would almost certainly be identified by the Attorney General as constituting an unjustified limitation on the right to freedom of expression. It would therefore be unlikely to be passed into law without an amendment to the threshold of harm. ${ }^{206}$

\section{$2 \quad$ Federal law}

Despite state participation in establishing cyber-bullying laws, there is currently no law addressing harmful digital communication in the United States at a federal level. While the Megan Meier Cyberbullying Prevention Act (the Megan Meier Act) ${ }^{207}$ was introduced in Congress in April 2009, it was never enacted. The Megan Meier Act was proposed to amend the federal criminal code to "impose criminal penalties on anyone who transmits in interstate or foreign commerce a communication intended to coerce, intimidate, harass, or cause substantial emotional distress to another person, using electronic means to support severe, repeated, and hostile behavior." ${ }^{208}$ Upon introduction, members of Congress dismissed the legislation as "an unconstitutional breach of free speech" and "another chapter of over-criminalization." ${ }^{209}$ Due to these concerns over the bill's limitation on the First Amendment right to freedom of expression, the bill never reached a vote. ${ }^{210}$

(a) New Zealand considerations

\footnotetext{
205 Bill of Rights Act, above n 73, s 7.

${ }^{206}$ For discussion on the effect of s 7 on Parliament's protection of the rights embodied in the NZBORA see Geoffrey Palmer and Matthew Palmer Bridled Power: New Zealand's Constitution and Government (4th ed, Oxford University Press, Melbourne, 2004) at 236.

${ }^{207}$ Megan Meier Cyberbullying Prevention Act H.R.1966. This Act was drafted in response to the cyber-bullying that led to the 2006 suicide of 13-year-old Megan Meier of Missouri.

${ }^{208}$ Megan Meier Cyberbullying Prevention Act above n 208.

${ }^{209}$ David Kravets "Cyberbullying Bill Gets Chilly Reception” (30 September 2009) <http://www.wired.com>.

${ }^{210}$ Benjamin Walther, above n 26, at 536.
} 
The United States' constitutional environment generally gives the government "no power to restrict expression because of its message, its ideas, its subject matter or its content," ${ }^{211}$ because of the primacy given to the First Amendment right to free speech. ${ }^{212}$ New Zealand, however, has not enacted a supreme constitution, and rights can be subject to certain justified limitations under section 5 of the NZBORA. ${ }^{213}$ Therefore, legislation that is deemed unconstitutional in the United States may appear to be much more acceptable in New Zealand. This is not the case with the Megan Meier Act, however. The provision only contained a requirement of intention on the part of the communicator, with no reference to harm caused to the victim, either subjective or objective. The provision would not satisfy the section 5 test for this reason. By omitting any harm requirements, the offence would allow too many instances of digital communications to be criminalised. The chilling effect this provision would have on freedom of expression is significant. As with the provision enacted in New York discussed above, the offence set out in clause 19 of the Harmful Digital Communications Bill is preferable to legislation of this kind, as intention alone is not sufficient to ensure that only the most serious digital harms are criminalised.

\section{United Kingdom}

In the United Kingdom, harmful digital communications are targeted through two different statutes. The first is the Malicious Communications Act 1988. Section 1 applies where a person sends an electronic communication to another that is indecent or grossly offensive, conveys a threat, or which is false, provided there is an intention to cause distress or anxiety to the recipient. ${ }^{214}$ The terms "indecent or grossly offensive" were said to be ordinary English words in the case of Connolly $v$ DPP..$^{215}$ As Lord Bingham made clear in DPP v Collins, “(t)here can be no yardstick of gross offensiveness otherwise than by the application of reasonably enlightened, but not

\footnotetext{
${ }^{211}$ United States $v$ Stevens, 559 US 460 at 5.

${ }^{212}$ United States $v$ Stevens, above $\mathrm{n} 211$ at 5.

${ }^{213}$ For a comparison of various countries bills of rights see Grant Huscroft "Rights, Bills of Rights and the Role of Courts and Legislatures" in Litigating Rights: Perspectives from Domestice and International Law ed Grant Hushcroft and Paul Rishworth (2002, Hart Publishing, Oxford, Portland Oregon).

${ }^{214}$ Malicious Communications Act 1998 (UK), s 1.

${ }^{215}$ Connolly v DPP [2007] 1 ALL ER 1012 at [10].
} 
perfectionist, contemporary standards to the particular message sent in its particular context". 216

The second is the Communications Act 2003. Section 127 can also be used to apply to instances of cyber-bullying. ${ }^{217}$ This provision makes it an offence to send or cause to be sent through a "public electronic communications network" a message or other matter that is "grossly offensive" or of an "indecent, obscene or menacing character". The same section also states that it is an offence to send or cause to be sent a false message "for the purpose of causing annoyance, inconvenience or needless anxiety to another." This requires that the defendant either intended or was aware that the message was grossly offensive, indecent or menacing, which can be inferred from the circumstances. There is no actual harm requirement, and the intended recipient need not be offended by or even in fact receive the message. ${ }^{218}$

In the case of Chambers $v D P P$, it was argued that a publically viewable message sent on the social networking platform "Twitter" could not be included under section 127 because, as a privately owned company, Twitter did not constitute a "public communications network". ${ }^{219}$ The High Court disagreed, finding because Twitter could not be operated without use of the internet, which it found is a public communications network, the fact of Twitter's private ownership was irrelevant. ${ }^{220}$ Accordingly, the Court found that messages sent using Twitter do fall within the ambit of section $127 .{ }^{221}$ Because many communications sent via social media are similarly accessible only to those who have access to the internet, the same presumably applies to any such communications.

\section{$1 \quad$ New Zealand Considerations}

The relevant legislation in the United Kingdom differs from clause 19 of the Harmful Digital Communications Bill in a number of material ways. There is no subjective

\footnotetext{
${ }^{216}$ DPP v Collins [2006] UKHL 40 at [9] per Lord Bingham.

${ }^{217}$ Communications Act 2003 (UK), s 127.

${ }^{218}$ DPP v Collins, above n 216 at [25] per Lord Brown.

${ }^{219}$ Chambers v DPP [2012] EWHC 2157 at [21].

${ }^{220}$ At [23].

221 At [25].
} 
harm element in either section 1 or section 127 , and only section 127 requires intention on the part of the communicator. While the test does require some objective harm, the standards of grossly offensive, indecent, obscene or menacing have the potential to be significantly broader than the "serious emotional distress" requirement set out in the Bill. As with the United States proposed legislation, the effect of these variations is that the limitation the provisions impose on the right to freedom of expression is greater than in the Harmful Digital Communications Bill, because it will be capable of applying to a great number of situations.

There also appears to be significant overlap in the two offences. This was most likely not foreseen when the Communications Act was enacted in 2003, as social media was not yet the influential forum for communication it has since become. The inclusion of Twitter in the interpretation of "public communications network" has created uncertainty as to how much further this may extend. ${ }^{222}$ By drafting more clearly defined legislation with modern technological advances in mind, the Harmful Digital Communications Bill is more suitable to address the concerns set out in the Law Commission's ministerial briefing paper.

\section{D $\quad$ Conclusion as to Foreign Jurisdictions}

The Harmful Digital Communications Bill would not be improved if it were to incorporate aspects of the laws discussed above. The Australian Department of Communications' suggestion for a separate offence for youth offenders is potentially useful in limiting clause 19's intrusion into freedom of expression. However, it goes too far in restricting the offence's ability to achieve Parliament's objective of preventing harmful digital communications. This is due to the prevalence of adolescent cyber-bullying, which the Law Commission highlighted as a major concern. ${ }^{223}$ Both the Australian and American state level legislation is overly restrictive in its exclusion of harmful digital communications between adults. Further, the harm required in the New York cyber-bullying law is too wide to amount to a demonstrably justified limitation on freedom of expression in New Zealand. In terms of freedom of expression, the Harmful Digital Communications Bill is also superior in

\footnotetext{
${ }^{222}$ Allisdair A Gillespie "Twitter, Jokes and the Law" (2012) 76 J Crim L 364 at 368.

${ }^{223}$ Harmful Digital Communications, above n 9, at [2.28].
} 
its inclusion of intention as well as both subjective and objective requirements under the criminal offence. This is in contrast with the Megan Meier Act and both United Kingdom provisions. The Harmful Digital Communications Bill is similarly preferable due to its inclusion of a civil enforcement regime, which provides a vehicle to address the actual harm caused rather than simply penalising offenders who cause it.

\section{Conclusion}

This paper has examined the serious consequences of harmful digital communications and cyber-bullying, and the inability of the current law to address the harm caused. The Law Commission attempted to remedy this inadequacy by proposing a number of new laws aimed at preventing and mitigating the harm caused by harmful digital communications. Among these suggestions were the establishment of a new civil enforcement regime and the creation of a criminal offence of causing harm by posting a digital communication, both of which were included in the resulting Harmful Digital Communications Bill. These two areas of the Bill were the focus of this paper, which considered their compatibility with the NZBORA, given the restriction they place on the right to freedom of expression.

In order to examine this limitation in a theoretical sense, the paper first considered whether harmful digital communications are defensible under the underlying rationales of freedom of expression. While the rationales of discovery of truth, selffulfilment and participation in democracy are capable of justifying the right to free political speech, they do not provide a convincing argument for the absolute protection of harmful digital communications and cyber-bullying.

This paper also considered in some depth the Bill's limitation on freedom of expression in light of the legal requirement of demonstrable justification under section 5 of the NZBORA. This discussion revealed that, while the civil enforcement regime represents a justified limitation on the right to freedom of expression, the offence of causing harm by posting a digital communication does not. Upon undertaking a section 5 analysis of clause 19, it became apparent that the offence represents a limit 
that is greater than reasonably necessary to achieve Parliament's objective. This is because the wording of the offence is broad enough to cover speech that, although harmful to a particular person, is of significant public utility. The paper proposed that the offence be amended to include a public interest defence. This would allow the Court discretion to refrain from criminalising harmful digital expression where it is in the public interest to do so. The inclusion of a public interest defence would allow Parliament's objective to be achieved at a lower cost to the right to freedom of expression.

Finally, the paper looked at laws enacted in other jurisdictions aimed at achieving a similar objective to the Harmful Digital Communications Bill. It concluded that the Bill provides the most appropriate framework for New Zealand to address the unique harms identified in the Law Commission's ministerial briefing paper on the topic. Despite this, the current Bill should not be passed without amendments. The most pressing concern is the inclusion of a public interest defence to the criminal offence at clause 19 . This should be achieved by way of a supplementary order paper at the time at which the paper has its second reading. In order for this offence to meet the requirement set out in section 5 of the NZBORA, a public interest defence is essential to prevent the offence from having an overly chilling effect on the right to freedom of expression. 


\section{Bibliography}

A Cases

$1 \quad$ New Zealand

Brooker v Police [2007] 3 NZLR 91.

Duff v Communicado Ltd [1996] 2 NZLR 89.

Hansen v R [2007] 3 NZLR 1 (SC).

Hosking v Runting [2005] 1 NZLR 1.

Lange v Atkinson [2000] 1 NZLR 257 (PC).

Ministry of Health v Atkinson [2012] 3 NZLR 456 (CA).

Ministry of Transport $v$ Noort [1992] 3 NZLR 260 (CA).

Moonen v Film and Literature Board of Review [2000] 2 NZLR 9 (CA).

Siemer v Solicitor-General [2013] NZSC 68.

Thompson v Police [2013] 1 NZLR 848.

$2 \quad$ Australia

Crowther v Sala 170 A Crim R 389 [2008] 1 Qd R 127.

$R v$ Hampson [2011] QCA 132.

$3 \quad$ United States of America

Abrams v United States, 250 US 616 (1919).

United States v Stevens, 559 US 460.

Whitney v California (1927) 274 US 357.

$4 \quad$ United Kingdom

Campbell v MGN Ltd [2004] 2 AC 457 (HL).

Chambers v DPP [2012] EWHC 2157.

Connolly v DPP [2007] 1 ALL ER 1012.

DPP v Collins [2006] UKHL 40.

$R v$ Secretary of State for the Home Department [2000] 2 AC 115 (HL).

The People v Marquan M (2014) NY Ct App 139.

$5 \quad$ Canada

$R v$ Oakes [1986] 1 SCR 103.

Vancouver (Cil) v Zhang 2010 BCCA450.

\section{B Legislation}

$1 \quad$ New Zealand 
Crimes Act 1961.

Education Act 1989.

Harmful Digital Communications Bill 2013 (168-2).

New Zealand Bill of Rights Act 1990.

Sentencing Act 2002.

$2 \quad$ Australia

Crimes Act 1900 (NSW).

Commonwealth Criminal Code Act 1995.

$3 \quad$ United States of America

Albany County Local Law No. 11 of 2010.

Dignity for All Students Act (2010) (NY).

Megan Meier Cyberbullying Prevention Act H.R.1966.

$4 \quad$ United Kingdom

Communications Act 2003.

Malicious Communications Act 1998.

\section{Books and Chapters in Books}

Eric Barendt Freedom of Speech (Oxford University Press, Oxford, 1985).

Andrew Butler and Petra Butler The New Zealand Bill of Rights Act: a commentary (LexisNexis, Wellington, 2012).

Claudia Geiringer and Steven Price "Moving From Self-Justification to Demonstrable Justification - the Bill of Rights and the Broadcasting Standards Authority" in Jeremy Finn and Steven Todd (eds) Law, Liberty, Legislation: Essays in Honour of John Butler QC (LexisNexis NZ, Wellington, 2008)

Grant Huscroft "Rights, Bills of Rights and the Role of Courts and Legislatures" in Litigating Rights: Perspectives from Domestice and International Law ed Grant Hushcroft and Paul Rishworth (2002, Hart Publishing, Oxford, Portland Oregon).

Elisabeth McDonald Principles of Evidence in Criminal Cases (Thomson Reuters, Wellington, 2012).

John Stuart Mill On Liberty (Cambridge University Press, 1959).

Dan Olweus Bullying At School: What We Know and What We Can Do (Oxford, UK, 1993).

Alexander Meiklejohn Free Speech and its Relation to Self-Government, reprinted in Political Freedom: The Constitutional Powers of the People (New York, 1965). 
Geoffrey Palmer and Matthew Palmer Bridled Power: New Zealand's Constitution and Government (4th ed, Oxford University Press, Melbourne, 2004).

Paul Rishworth and others The New Zealand Bill of Rights (Oxford University Press, Melbourne, 2003).

Wojciech Sadurski Freedom of Speech and Its Limits (Kluwer Academic Publishers, Massachusetts, 1999).

\section{Journal Articles}

Andrew Ashworth and Lucia Zedner "Prevention and Criminalization: Justification and Limits" (2012) 15 New Crim L Rev 542.

Colleen Barnett "Cyberbullying: A New Frontier and a New Standard; A Survey of and Proposed Changes to State Cyberbullying Statutes" (2009) 27 Quinnipiac L. Rev. 579.

Darryn Cathryn Beckstrom "State Legislation Mandating School Cyberbullying Policies and the Potential Threat to Students' Free Speech Rights" 33 (2008) VT L REV 283.

A Brunstein Klomek, A Sourander and M Gould "The association of suicide and bullying in childhood to young adulthood: a review of cross-sectional and longitudinal research findings" (2010) 55 Can J Psychiatry 282.

Des Butler, Sally Kift and Marilyn Campbell "Cyber bullying in Schools and the Law: Is There an Effective Means of Addressing the Power Imbalance?" (2009) 16 Murdoch University Electronic Journal of Law 84.

Allisdair A Gillespie "Twitter, Jokes and the Law" (2012) 76 J Crim L 364.

Vanessa A Green and others "Bullying in New Zealand Schools: A Final Report" (2013) Victoria University of Wellington.

Kent Greenawalt “Free Speech Justifications” (1989) 89 Colum L Rev 119.

Michael J Higdon "To Lynch a Child: Bullying and Gender Nonconformity in Our Nation's Schools" (2011) 86 Ind L J 827.

Dianne L Hoff and Shaheen Shariff "Cyber bullying: Clarifying Legal Boundaries for School Supervision in Cyberspace" (2007) 1 International Journal of Cyber Criminology 76.

Alexander Meiklejohn "The First Amendment Is an Absolute" (1961) Supreme Court Review 245.

Juliet Moses "Hate Speech: Competing Rights to Freedom of Expression" (1996) 8 
Auckland U L Rev 185.

Alan R Regal "Hate Propaganda: A Reason to Limit Freedom of Speech" 1(984) 49 Sask LR 303.

Jacob H Rowbottom "To Rant, Vent and Converse: Protecting Low Level Digital Speech" (2012) 71 CLJ 355.

Robert Tokunaga "Following you home from school: A critical review and synthesis of research on cyberbullying victimization" (2010) 26 Computers in Human Behavior 277.

Alexander Tsesis "Dignity and Speech: The Regulation of Hate Speech in a Democracy” 200944 Wake For L Rev 497.

Lauren Vanga "Ending Bullying at a Price: Why Social Conservatives Fear Legislatively Mandated LBGT Indoctrination in Schools" (2014) 17 Chap L Rev 659. Benjamin Walther "Cyberbullying: Holding Grownups Liable For Negligent Entrustment" (2012) 49 Hous L Rev 531 at 532.

Daniel B Weddle "Bullying in Schools: The Disconnect Between Empirical Research and Constitutional, Statutory, and Tort Duties to Supervise" (2004) 77 Temp L Rev 641.

Hanna Wilberg, "The Bill of Rights and Other Enactments" [2007] NZLJ 112.

\section{E Parliamentary Materials}

$1 \quad$ Select Committee Submissions

Google "Submission of Google on the Harmful Digital Communications Bill".

Human Rights Commission "Submission to the Justice and Electoral Committee on the Harmful Digital Communications Act 2013".

New Zealand Police "Submission of New Zealand Police".

Steven Price "Submission on Harmful Digital Communications Bill”.

Tech Liberty “Submission: Harmful Digital Communications Bill”.

\section{F Governmental Reports}

$1 \quad$ New Zealand

Prime Minister's Chief Science Advisor Improving the Transition: Reducing Social and Psychological Morbidity During Adolescence (Office of the Prime Minister's Science Advisory Committee, May 2011). 
Ministry of Justice Harmful Digital Communications Bill - Initial Briefing (6 March 2014).

$2 \quad$ Australia

Australian Department of Communications Enhancing Online Safety for Children:

Public consultation on key election (January 2014).

\section{G Law Commission Materials}

New Zealand Law Commission Harmful Digital Communications: The Adequacy of the Current Sanctions and Remedies (Wellington, 2012).

\section{H Online Resources}

Sam Boyer "Calls go out for "Charlotte's Law" <www.nzherald.co.nz>.

Simon Collins and Vaimoana Tapaleao "Suicide link in cyber-bullying"

<www.nzherald.co.nz>.

Commonwealth Director of Public Prosecutions "Case Report - Bradley Paul

Hampson" <www.cdpp.gov.au>.

Michael Dickison "News about abusive texts stuns parents of dead girl"

<http://www.nzherald.co.nz>

Colin Gavaghan "Cyber-bullying and the law" $<$ https://blogs.otago.ac.nz>.

Amanda Gillies "Call for cyber bullying law after death" <www.3news.co.nz>.

Melissa Hale-Spencer "State's Top Court questions Efficacy of Cyberbullying Law"

(6 June 2014) <www.altamontenterprise.com>.

Abigail Hartevelt "Call for new cyber bullying laws" <www.nzherald.co.nz>.

Sameer Hinduja and Justin Patchin "Description of State Cyberbullying Laws and

Model Policies" (2014) <www.cyberbullying.us>.

Human Rights Commission "Harmful Digital Communications Bill” (media release, 20 March 2014) <www.hrc.co.nz>.

Tony Kiem "Facebook troll Bradley Paul Hampson jailed for posting child porn on tribute pages for dead children" (March 25, 2011) <www.couriermail.com.au>.

David Kravets “Cyberbullying Bill Gets Chilly Reception” (30 September 2009) <http://www.wired.com>.

Josh Taylor "Government has no plans for "Charlotte's Law" <www.zdnet.com>. 
"What's wrong with the Communications (New Media) Bill and can it be fixed?" 2 September $2012<$ http://techliberty.org.nz>.

"Bond for abuse texts to friend" (11 December 2010) <www.qt.com.au>. 